\title{
Bilişsel Davranış Değiştirme ve Motivasyonel Görüşme
}

\author{
M. Zeki İlgar ${ }^{1}$, Semra Coşgun-İlgar ${ }^{1}$ \\ ${ }^{1}$ Eğitim Bilimleri Bölümü, Eğitim Fakültesi, Biruni Üniversitesi, İstanbul, Türkiye
}

Sorumlu Yazar: M. Zeki İlgar, zilgar@biruni.edu.tr

Makale Türü: Derleme Makale

Kaynak Gösterimi: İlgar, M. Z., \& Coşgun-İlgar, S. (2019). Bilişsel davranış değiştirme ve motivasyonel görüşme. Eğitimde Kuram ve Uygulama, 15(1), 47-73. doi: 10.17244/eku.489855

\section{Cognitive Behavioral Change and Motivational Interviewing}

$$
\text { M. Zeki İlgar }{ }^{1} \text {, Semra Coşgun-İlgar }{ }^{1}
$$

${ }^{1}$ Department of Educational Sciences, Faculty of Education, Biruni University, İstanbul, Turkey

Corresponding Author: M. Zeki İlgar, zilgar@biruni.edu.tr

Article Type: Review Article

To Cite This Article: İlgar, M. Z., \& Coşgun-İlgar, S. (2019). Bilişsel davranış değiştirme ve motivasyonel görüşme. Ĕ̆itimde Kuram ve Uygulama, 15(1), 47-73. doi: 10.17244/eku.489855 


\title{
Bilişsel Davranış Değiştirme ve Motivasyonel Görüşme
}

\author{
M. Zeki İlgar ${ }^{1}$, Semra Coşgun-İlgar ${ }^{1}$ \\ ${ }^{1}$ Ĕgitim Bilimleri Bölümü, Eğitim Fakültesi, Biruni Üniversitesi, İstanbul, Türkiye \\ ORCID: https://orcid.org/0000-0002-5516-0752 \\ ORCID: https://orcid.org/0000-0002-1436-1666
}

\begin{tabular}{|c|c|}
\hline$\ddot{\mathbf{O} z}$ & Makale Bilgisi \\
\hline $\begin{array}{l}\text { Bu çalışmada Bilişsel Davranış Değiştirme'nin özel eğitim, psikolojik danışma ve } \\
\text { psikoterapi alanlarında kullanımını ele almak ve bu alanlarda çalışanlara yardımcı olmak } \\
\text { amaçlanmıştır. Çalışma hem teorik ve uygulamalı araştırmalara yer vererek kanıta dayalı } \\
\text { örnekler sunması; hem de ülkemizde az çalışılan bir konuya açıklık getirmesi ve dikkat } \\
\text { çekmesi açısından önemli görünmektedir. Doküman incelemesi yöntemiyle yapılan bu } \\
\text { çalışmada sırasıyla şu konulara yer verilmiştir: (a) Davranış kavramı , (b) Bilişsel }\end{array}$ & $\begin{array}{l}\text { Anahtar Kelimeler: Bilişsel } \\
\text { davranış değiştirme, Bilişsel } \\
\text { davranışçı terapi, Motivasyonel } \\
\text { görüşme }\end{array}$ \\
\hline $\begin{array}{l}\text { Davranış Değiştirme'nin tanımı, temel varsayımları, diğer davranış değiştirme } \\
\text { yöntemlerinden farklılıklar, (c) Bilişsel Davranışçı Terapi'nin Bilişsel Davranış } \\
\text { Değiştirmede kullanımı, (d) Bilişsel Davranışçı Terapi’nin anksiyeteli çocukların } \\
\text { tedavisinde kullandığı teknikler, (e) Bilişsel Davranışçı Terapi'nin Özel Eğitim, Psikolojik }\end{array}$ & $\begin{array}{l}\text { Makale Geçmişi: } \\
\text { Geliş: } 29 \text { Kasım } 2018 \\
\text { Düzeltme: } 26 \text { Şubat } 2019 \\
\text { Kabul: } 21 \text { Mart } 2019\end{array}$ \\
\hline $\begin{array}{l}\text { Danışma Ve Psikoterapide kullanımına ilişkin araştırma sonuçları, (f) Bir davranış } \\
\text { değiştirme tekniği olarak Motivasyonel Görüşme yaklaşımı ve Bilişsel Davranışçı Terapi } \\
\text { entegrasyonunun depresyon tedavisinde kullanımına ilişkin bir uygulama örneği. }\end{array}$ & $\begin{array}{l}\text { Makale Türü: Derleme } \\
\text { Makale }\end{array}$ \\
\hline
\end{tabular}

\section{Cognitive Behavioral Change and Motivational Interviewing}

\begin{tabular}{|c|c|}
\hline Abstract & Article Info \\
\hline $\begin{array}{l}\text { In this study, it is aimed to analyze the use of Cognitive Behavioral Change in special } \\
\text { education, psychological counseling and psychotherapy and to help professionals in that } \\
\text { fields. The study seems crucial to provides evidence - based examples including both } \\
\text { theoretical and practical researches; it sheds light on and points out a topic that is less } \\
\text { studied by researchers until today. Document analysis method is used in this study. The } \\
\text { main issues analyzed in the study are: (a) The concept of behavior, (b) Definition of }\end{array}$ & $\begin{array}{l}\text { Keywords: Cognitive } \\
\text { behavioral change, Cognitive } \\
\text { behavioral therapy, } \\
\text { Motivational interviewing }\end{array}$ \\
\hline Cognitive Behavioral Change, basic assumptions and its differences from other behavioral & Article History: \\
\hline change methods, (c) The use of Cognitive Behavioral Therapy in Cognitive Behavioral & Received: 29 November 2018 \\
\hline Change, (d) The techniques used by Cognitive Behavioral Therapy in the treatments of & Revised: 26 February 2019 \\
\hline children with anxiety, (e) Research results on the use of Cognitive Behavioral Therapy in & Accepted: 21 March 2019 \\
\hline $\begin{array}{l}\text { Private Education, Psychological Counseling and Psychotherapy, (f) An application } \\
\text { example of the use of Motivational Interviewing approach and Cognitive Behavioral } \\
\text { Therapy integration as a behavioral change technique. }\end{array}$ & Article Type: Review Article \\
\hline
\end{tabular}




\section{Davranış nedir?}

Davranış kavramını canlı organizmaların dışarıdan gözlenebilen ve sonuçlarından tespit edilebilen tepkileri olarak tanımlamak mümkündür. İnsan davranışlarını incelediğimizde; davranışın oluşumunda güdülerin, duyguların, kişilik özelliklerinin, genetik kapasitenin, gelişim sürecinin ve öğrenmelerin etkisi olduğunu görürüz. Dışarıdan alınan uyarıcılar içeriden gelen uyarıcılarla etkileşerek bilişsel alanda birtakım işlemlerden geçerek tepkilerin meydana gelmesini sağlamaktadır. Sadece bir uyarıcı birden fazla tepkiye yol açabileceği gibi bir tepki birden çok uyarıcıdan etkilenerek te oluşmuş olabilir.

Baymur (1994), herhangi bir uyarıcı karşısında bireyin nasıl davranacağını kestirebilmek için onun hakkında şu bilgilere sahip olmak gerektiğini ifade etmektedir: a. Biyolojik Özellikler: Bireyin hangi gelişim döneminde olduğu, zeka düzeyi, cinsiyeti, ilgi ve yetenekleri. b. Geçmiş Yaşam: Bireyin yaşadığ yerleşim birimleri, eğitim geçmişi, başından geçen olaylar, bilgi ve alışkanlıkları. c. Anlık İçsel Durumu: Bireyin ruh hali, aç ya da tok oluşu, dinlenmiş veya yorgun oluşu, istekli veya isteksiz oluşu. d. İçinde Bulunduğu Çevre Koşulları: Mevsim, 1s1-1şık ve ses etkileri, yalnız veya grup içinde olunması.

\section{Davranış Türleri}

Psikoloji literatüründe insan davranışlarının farklı şekillerde sınıflandırıldığını görmekteyiz. En geniş anlamda kabul gören sinıflandırmaya göre:

a. Doğuştan Gelen Davranışlar: İçü̈üsel davranışlar, refleksif tepkiler,

b. Geçici Davranışlar: Alkol, ilaç, hastalık etkisiyle oluşan davranışlar,

c. Sonradan Kazanılan Davranışlar: Öğrenme ürünü olan davranışlar.

Aile, okul ve sokak ortamlarında gerçekleşen sonradan kazanılan öğrenme ürünü olan davranışlar da iki çeşittir: a. İstendik Davranışlar: Planlı eğitimin ürünü olan davranışlar (Aile kültürünün edinilmesi, akademik becerilerin kazanılması vb.). b. İstenmedik Davranışlar: Uygun olmayan koşullarda kazanılan ve eğitimin hatalı ürünü davranışlar (küfretmeyi, sigara, alkol, uyuşturucu kullanmayı öğrenme).

\section{Bilişsel Davranış Değiştirme}

Bilişsel davranış değiştirme hem bilişsel hem de davranışsal öğrenme prensipleri içeren bir müdahale yöntemidir. Aslında "bilişsel davranış değiştirme" şu 3 varsayımı içeren teorik ve pratik yaklaşımları temsil eder: a) Bireyin davranışları bilişsel olaylarla belirlenir, b) Bilişsel olaylardaki bir değişim davranışta da değişikliğe neden olur, c) Birey kendi öğrenme sürecinde aktif bir katılımcıdır. Kısacası, bilişsel davranış yaklaşımı bireylerin kendi davranışlarını izleme ve yönetmede kendi kapasite ve tercihlerinin etkili olduğunu kabul eder (Heflin ve Simpson, 1998).

Bilişsel davranış değiştirme yöntemi bireye kendi davranışı, tutum ve performansını izlemeyi ve uygun şekilde iç-pekiştirmeyi öğretmeyi hedeflemektedir. $\mathrm{Bu}$ bağlamda; bilişsel davranış değiştirme, düşünceyi değiştirmenin duygu ve davranışı değiştirmedeki önemini vurgulamaktadır (Corey, 1991; Harris, 1988). Öğretmen, öğrencinin düşüncesini ve davranışını değiştirmek için onun bilişsel süreçlerini aktifleştirmeye çalışır. Meichenbaum'e (1980) göre; bilişsel davranış değiştirme, bireyin şu kabiliyetleri geliştirmesine bağlıdır: a) Nasıl hissettiği, düşündüğ̈̈ ve davrandığını fark etme, b)Kendi davranışının başkalarına etkisini fark etme.

Kaplan ve Carter'e (1995) göre; bilişsel davranış değiştirmeyi diğer davranış yönetim tekniklerinden ayıran aşağıdaki 5 özellik şunlardır:

-Başlıca değişimi yaşayan başkalarından çok katılımcıların kendisidir.

-Durumu ifade etme açıtan aleni şekilde başlar. Daha sonra öz-izleme seviyesinde ve son olarak gizli olarak gerçekleşir.

•Katılımcılar bir dizi problem çözme basamağını tanımlamayı ve kullanmayı öğrenirler.

-Modelleme yöntemi kullanılır.

• Bilişsel davranış değiştirme kendine hakim olmayı kolaylaştırır.

Bilişsel davranış değiştirme hem bilişsel hem de davranışsal yönleri olan bir tekniktir. O öz denetlemeyi arttırmak için oluşturulmuştur. Öz- denetleme ile bireyin kendi davranışını ve performansını izlemesi ve bununla birlikte istenilen davranışı pekiştirmesi beklenir. Yapılan çalışmalar, birçok bilişsel davranış değiştirme metodunun 
engelli bireylerle çalışırkenki etkinliğini ortaya koymaktadır. Otizmli bireylere yapılan müdahaleler için ümit vaat etmektedir. Psikoljik danışma ve psikoterapide bilişsel yaklaşımın temelleri Albert Ellis ve Aaron T. Beck tarafından 1970’li yılarda atılmıştır. Beck'in 1960'lı yıllarda depresif bireyler üzerinde yaptığı çalışmalar bilişsel terapilerin doğuşunu hazırlamıştır (Karahan \& Sardoğan, 2004)

\section{Çocukluk Çăğ Anksiyete Bozukluklarının Tedavisinde Bilişsel Davranışçı Terapi’de Kullanılan Teknikler}

Bilişsel Davranışçı Terapi 'nin öncelikli hedefi, anksiyeteyi tetiklediği düşünülen bilgi işleme süreçlerindeki yanlılık ve çarpıtmaların değiştirilmesi ile bu bilişsel bozulmanın yarattığ işlevsel olmayan kaçma/kaçınma tipi baş etme örüntüsünün önüne geçilmesidir. Dolayısıyla, çocukluk çağında görülen anksiyete bozukluğunun Bilişsel Davranış̧̧ Terapi 'yle tedavisinde, davranışçı teknikler ile bilgi işleme süreçlerine ilişkin bozulmuş öğelerin yeniden yapılandırılmasını sağlayan bilişsel tekniklerin kombinasyonu kullanılmaktadır (Kendall \& Suveg, 2006). Aşağıda, Bilişsel Davranışçı Terapi ’de kullanılan başlıca teknikler belirtilmiş ve kısaca açıklanmıştır.

a. Psikoeğitim: Psikoeğitimin temel amacı, terapi süresince çocuğun, pek çok farklı boyut açısından (örneğin, doğası, bileşenleri gibi) anksiyete hakkında bilgi sahibi olmasıdır. Bu eğitimin sonucunda çocuk, kendisinin ve diğerlerinin duygusal süreçlerini ayırt edebilip, bunları doğru biçimde ifade edebilmektedir. Ayrıca, anksiyeteli çocukların ortak özelliklerinden biri, kaygı ve korku hissettiklerinde karın ağrısı, nefes darlığı, baş ağrısı gibi çeşitli fizyolojik belirtiler yaşamalarıdır. Dolayısıyla, bu fizyolojik belirtilerin doğasını, hangi durumlarda ne şekilde ortaya çıktıklarını, anksiyete hissini nasıl tetiklediğini ya da alevlendirdiğini bilmeleri, bunlarla baş edebilmeleri için bir ön koşuldur. Sonuç olarak, psikoeğitimin temel rasyoneli, kendi anksiyetesini iyi şekilde tanımlayıp diğer durumlardan ayırt edebilen çocuğun, bu yoğun duyguyla etkili biçimde baş edebileceği yönündedir (Beidas, Podell \& Kendall, 2008; Kendall \& Suveg, 2006).

b. Gevşeme Teknikleri: Çocukluk çağı anksiyete bozuklukları tedavisinde gevşeme tekniklerine başvurulması, çocuğun baş etme becerilerini geliştirmekte ve anksiyete karşısında kendisini daha güçlü görmesini sağlayarak özyeterliliğini arttırmaktadır (Freeman, Pretzer, Fleming \& Simon, 2004).

Anksiyete bozukluklarının tedavisinde gevşeme teknikleri, korku, kaygı, öfke gibi duyguları tetikleyen uyaranların varlığında psikofizyolojik uyarılma düzeyini azaltmak üzere kullanılmaktadır. Dolayısıyla, gevşeme egzersizlerinin temel hedefi, çocuğun anksiyete karşısında oluşan kendi öznel kas ve beden reaksiyonlarının çocuk tarafindan fark edilmesi ve çocuğun bu fizyolojik tepkileri kontrol etmeyi öğrenmesidir (Beidas, Podell \& Kendall, 2008; Kendall \& Suveg, 2006). Çocuklarda kullanılan gevşeme teknikleri, derinlemesine nefes egzersizi ve kas gevşetme yöntemi olarak iki farklı şekilde uygulanabilmektedir.

Anksiyete bozukluğu olan çoğu çocuk, kaygı yaratan bir durumla karşılaştıklarında nefes darlığı hissettiklerini ya da soluma süreleri kısaldığı için nefes nefese kaldıklarını bildirmektedir. Anksiyete durumunda kesik kesik alınan hava, ciğerlerin yalnız üst kısmını doldurmakta, beyne giden oksijen miktarı azalarak bedensel bir gerginlik oluşmaktadır. Dolayısıyla, derin ve diyafram kullanılarak alınan nefes, solunumu ritmik ve düzenli bir hale sokacağı için alarm durumundaki sinir sistemini bir miktar sakinleştirmektedir (Kendall \& Suveg, 2006).

Derin nefes alma egzersizinde, çocuktan gözlerini kapatması, burnundan derin bir nefes alması, daha sonra da aldığı bu nefesi yavaşça dışarı bırakması istenmektedir. Alınan nefesin göğüs kafesini değil, diyaframı aşağı doğru iterek karnı dolduruyor olması, eğitimde en çok üzerinde durulması gereken kısımdır (Roskies \& Albrecht, 1998). Diyafram nefesinin öğretilmesi, özellikle hedef grup çocuksa oldukça zor olabilmektedir. Bu sebepten ötürü, çocuğu bir mindere yatırarak ve karnına kitap gibi bir ağırlık yerleştirilerek nefes almasını istemek ve karnının yukarı-aşağ hareket ettiğinden emin olmak, kullanılabilecek pratik bir yöntemdir.

İkinci aşama olan kas gevşetme tekniğinin amacı ise, kaygıyla ilişkili olan kas gerginliğini azaltmak ve bu gerginliğin anksiyete belirtilerini daha da şiddetlendirmesini önlemektir. Bu teknikle, parasempatik sinir sisteminin etkinliğinin arttığı bir durum yaratılmakta ve anksiyete anında uyarılmış olan sempatik sinir sisteminin etkinlik düzeyinde bir gerileme sağlanmaktadır (Demiralp \& Oflaz, 2007). Aşamalı kas gevşetme eğitiminde öncelikle, bedenin temel kas grupları çocuğa tanıtılmakta ve ardından bu kas gruplarının aşamalı olarak gerip gevşetilmesi 
sağlanmaktadır. Bu germe-gevşetme aşamasında çocuk, kasları gerginken bedenindeki değişimleri öğrenmektedir (Beidas, Podell \& Kendall, 2008; Kendall \& Suveg, 2006).

Ayrıca, kas gruplarına ilişkin bilgilendirme sırasında çocuk, kaygılıyken hangi beden bölgelerinin etkilendiğini fark ederek, anksiyete yükselmeden kendine özgü bir "erken alarm sistemi" oluşturabilmekte ve anksiyete yaratan durumla yüz yüze geldiğinde gevşeme tekniklerini hemen uygulamaya başlayabilmektedir. Bu farkındalık sonucu, pratikte uygulaması uzun sürebilen kas gevşetme tekniğini çocuk kendine uyarlayabilmekte ve yalnızca sorunlu kas gruplarına odaklanarak, anksiyete durumundayken daha kısa ve etkili bir gevşeme uygulayabilmektedir (Beidas, Podell \& Kendall, 2008; Kendall \& Suveg, 2006).

Aşamalı kas gevşetme tekniği öğretilirken, germe-gevşetme egzersizlerindeki hareketlerin eğlenceli somut örnekler kullanılarak çocuğa öğretilmesi, hem çocuğun egzersizi uygulamaya ilişkin isteğini arttırmakta hem de hareketlerin hatırlanabilirliğini güçlendirmektedir. Örneğin, el kaslarıyla çalışılırken, çocuğa elinde bir limon olduğunu hayal etmesi ve suyunu çıkartmak için onu sıkması istenmekte, böylelikle gevşeme egzersizi daha eğlenceli ve daha akılda kalan bir hal almaktadır (Beidas, Podell \& Kendall, 2008; Kendall \& Suveg, 2006).

Özellikle bu tekniği yapmak isteyen ancak anksiyete durumunda topluluk içinde utandığı için tekniği gerektiği şekilde uygulayamayan çocuklarda, "ipucu-kontrollü gevşeme" yöntemi işe yarayabilmektedir. Bu yöntemde, seans sırasında yaptırılan aşamalı kas gevşetme egzersizinin sonunda, çocuk tam bir gevşeme durumuna ulaştığında, bu rahatlama halini ona hatırlatacak bir kelime yüksek sesle söylenmektedir (örneğin, sakin gibi). Dolayısıyla, söylenen kelime ile gevşeme hali eşleşmekte ve ileride oluşan herhangi bir anksiyete durumunda, ortam uygun olmadığ için tekniği uygulayamayan çocuk bu kelimeyi kendine söyleyerek rahatlayabilmektedir (Beidas, Podell \& Kendall, 2008; Kendall \& Suveg, 2006).

c. Dikkat Kaydırma Tekniği: Anksiyete bozukluğu olan çocukların çoğu, kaygı yaratan bir düşünce akıllarına geldiğinde dikkatlerini tamamen bu olumsuz düşünce üzerine odaklamakta ve seçici dikkat, anksiyeteyi daha da körüklemektedir. Dolayısıyla, dikkatin anksiyete yaratan düşünceden, nötr ya da rahatlatıcı bir zihinsel aktiviteye kaydırılması, çocuğun kaygısının azalmasında yardımcı bir teknik olarak kullanılmaktadır (Beidas, Podell \& Kendall, 2008; Kendall \& Suveg, 2006).

Bu zihinsel aktiviteler, sayı sayma, son harfle isim bulma gibi, zihni meşgul edecek nötr akı1 yürütmeler olabildiği gibi, çocuğun kendisini çok mutlu ve rahat hissedeceği bir yerde hayal etmesi ya da çok sevdiği bir şarkının sözlerini düşünmesi gibi düşünce aktiviteleri de olabilmektedir. Zihinde canlandırılan sahne ne kadar ayrıntılı olursa, çocuğun o kadar hızlı ve kolay rahatlayacağı varsayılmaktadır.

Dolayısıyla görüşme sırasında bu hayali çalışıp, terapistin çocuğa hayalini detaylandırması konusunda yardım etmesi oldukça faydalı olmaktadır (Beidas, Podell \& Kendall, 2008; Kendall \& Suveg, 2006; aktaran Tok, 2014, s.49$52)$.

d. Bilişsel Yeniden Yapılandırma: Bilişsel davranışçı kuramda, biliş, duygu ve davranış birbirinden ayrılamaz öğeler olarak kavramsallaştırılmaktadır; dolayısıyla, çarpıtılmış ya da gerçekçi olmayan bilişlerin tanımlanması ve yeniden yapılandırılması vasıtasıyla, duygu ve davranış alanlarındaki bozulmaların da iyileşeceği varsayılmaktadır. Yeniden yapılandırma ile kastedilen şey, işlevsel olmayan düşüncelerin, daha yapıcı düşünce stilleri ile yer değiştirmesi, bir anlamda düşüncede düzeltme yapılmasıdır (Ingram, Kendall \& Chen,1991).

Çocukluk çağı anksiyete bozukluklarının tedavisinde Bilişsel Davranışçı Terapi 'nin temel amaçları, çevrede olup biteni yorumlarken yapılan hataların ve buna bağlı oluşan kaygı yaratıcı olumsuz iç konuşmaların çocuk tarafından fark edilmesi, test edilmesi, azaltılması, bunların yerine koyabileceği mantığa dayalı olumlu iç konuşmaların üretilmesi ve gerçekçi olmayan olumsuz bilişsel çarpıtmalarla baş etmesidir. Bu bilişsel yapılandırma sürecinde sıklıkla kullanılan teknikler arasında, seans içi davranış provası, rol canlandırma egzersizi, kayıt tutma temelli ev ödevi ve seans için ödüllendirme sistemi gelmektedir (Beidas, Podell \& Kendall, 2008; Kendall \& Suveg, 2006).

Uyuma yönelik olmayan olumsuz iç konuşmalar, çocuğun bilişsel çarpıtmalarının bir eseridir. Bilişsel çarpıtmalar, eksik ya da yanlış bir bilgi işleme süreci neticesinde oluşan, çevreyi ve/veya diğerlerini ve/veya kendini yanlış yorumlamayla sonuçlanan ve çocukluk çağı içe yönelim sorunlarının etiyolojisinde önemli yer tutan bir kavramdır. Anksiyete bozuklukluğu olan çocuklarda en sık görülen bilişsel çarpıtmaların, felaketleştirme, ya hep ya 
hiç tarzı düşünme, aşırı genelleme, meli/malı tarzı düşünme, zihinsel süzgeç, aşırı büyütme/küçültme ve etiketleme olduğu çalışmalarca gösterilmektedir. Dolayısıyla, bilişsel yeniden yapılandırma aşamasında, çocuğun bilişsel çarpıtmalar hakkında da eğitim alması ve olumsuz iç konuşmalarını bu bilişsel hatalar çerçevesinde sokratik sorgulama yöntemi kullanarak değerlendirmesi Bilişsel Davranışçı Terapi açısından önemli bir adımdır (D’Eramo \& Francis, 2004).

Çocuklarla bilişsel yeniden yapılandırma sürecinde çalışılırken en çok dikkat edilmesi ve iyi değerlendirilmesi gereken nokta, işlevsel olmayan olumsuz düşüncelerin doğru biçimde kavramsallaştırılmasıdır. Çocuklar, gelişimsel özellikleri açısından duygu-düşünce-davranış üçlüsünü ayırt edebilmek için zamana ihtiyaç duymaktadırlar; dolayısıyla, bu beceriyi kazanabilmeleri için yeterince egzersiz yapmaları gerekmektedir. Doğrudan kendi kaygıları üzerinden örneklerle konuşmak çocukları rahatsız edeceği için, bu egzersiz dönemi genellikle hipotetik örneklerle yapılmakta, daha sonra çocuğun kendi kaygıları hakkında konuşulmaya başlanmaktadır (Beidas, Podell \& Kendall, 2008; Kendall \& Suveg, 2006; aktaran Tok, 2014, s.52-53).

Bilişsel yeniden yapılandırma; bilişsel baş etme stratejileri bireyin düşünce biçimini değiştirmesini içermektedir. Bu değişiklik birey stresle karşılaştığında daha soğukkanlı, gerçekçi ve olumlu düşünmesini, bunun sonucu olarak da duygusal olarak daha umutlu olmasını sağlamaktadır. Örneğin, zor bir ders alan öğrenci anksiyete, motivasyon eksikliği, cesaretin kırılması gibi durumları deneyimleyebilir ve bunun sonucu olarak da dersten tamamen uzaklaşabilir. Öğrencinin yaşadığı korku ve katastrofik düşünceler (Ör: hata yaparsam ne olur? gibi), daha fazla stres yaşamasına neden olmaktadır. Bilişsel baş etme stratejileri katastrofik düşüncelerin rasyonel düşünceler haline gelmesini sağlar ve bireyin stresörleri tehdit değil de bir firsat olarak görmesine yardım etmektedir. Bu yeniden yapılandırma süreci bilişsel yeniden yapılandırmall olarak adlandırılmaktadır (Bernstein, 2011). Bilişsel yeniden yapılandırma tekniği, en genel anlamıyla, olay veya uyarıcı hakkında yapılan değerlendirmelerin değiştirilmesine hizmet etmektedir (Rice, 1999; Onbaşıŏlu 2004). Bilişsel yeniden yapılandırma ilk önce stres yaratan düşünceleri tanımlamayı (asla onu anlayamam gibi) ve ardından stres altında iken daha olumlu düşünceleri kullanmayı (yapabileceğimin en iyisini yaptım gibi) sağlamaktadır. Bilişsel baş etme bireyin stresörlerini ortadan kaldırmaz, fakat onları daha az tehdit edici ve yıkıc1 alg1lamasına yardım etmektedir (Bernstein, 2011; Seaward, 2013).

Bilişsel yeniden yapılandırma tekniğinin bireye bu konuda eğitim almış bir uzman tarafından öğretilmesi gerekmektedir. Öncelikle bireyin çarpık düşünceleri ve irrasyonel inançlarının ele alınması gerekmektedir. Bu durumla uyumlu alternatif düşünceler ya da başa çıkma davranışları bireye kazandırılmalıdır. Bireye ABC modeli öğretilmeli ve bilişsel çarpıtmalar ve irrasyonel inançların bireyin stresli olaylar karşısında verdiği tepkileri nasıl etkilediği bireye gösterilmelidir. Bu süreçte, bireyin stres yaşamsına neden olan düşünceleri fark etmesine yardım etmek için bir düşünce kayıt formu tutması da sağlanmaktadır. Böylece bireyin stresli durumlarda ortaya çıan irrasyonel düşünceleri ile davranışları ve duyguları arasındaki ilişki bireye gösterilmiş olacaktır. Bilişsel yeniden yapılandırma ile hedeflenen bireyin stres düzeyini azaltarak, kontrol duygusunu artırmaktır (O`Donohue \& Fisher, 2008). Bilişsel yeniden yapılandırma tekniği, Şu amaçlara yönelik olarak kullanılmaktadır (Onbaşığlu, 2004):

Bireyin düşünceler arasında seçim yapılabileceğinin fark etmesini sağlamak. Bireyin bir düşünce yerine diğer düşünceyi seçmenin stres yaşantısı üzerindeki etkisini anlamasını sağlamak. Bireyin seçim hakkını olumlu ve işlevsel olan düşünceden yana kullanılmasını sağlayarak ve bu Şekilde stres deneyimlerinin yoğunluğunu azaltmak.

Bilişsel yeniden yapılandırma, bilişsel-davranışçı terapilerin en temel bileşenlerinden biridir. Hoş olmayan ve rahatsızlık veren duygu veya stres yaşantısı üzerine yapılan Bilişsel Davranışçı Terapilerde, danışanlara bu teknik öğretilmektedir. Danışan ile yapılan bilişsel yeniden yapılandırma çalışmasında amaç; danışana, rahatsız edici duygular yaşadığı durumlarda, stres tepkisini ve duygularını kontrol altına alabilmesi için uygun bilişsel baş etme tepkisinin kazandırılmasıdır. Danışan, bilişsel yeniden yapılandırma tekniğini, gündelik yaşamında uygulayabildiği takdirde, stresörler karşısında uygun düşünce, duygusal ve davranışsal tepkileri gösterebilecektir. Bilişsel yeniden yapılandırma için, bireyin ilk başta, stres tepkisinin hangi durumlarda, hangi olaylar ve uyarıcılar karşısında tetiklendiğinin farkına varması gerekmektedir. Diğer bir deyişle; bireyden stres yaşantısının farkına varması ve o an içinde bulunduğu durumun, karşılaştığı uyarıcının kendisi için bir stresör niteliğinde olduğunu anlaması beklenmektedir (Onbaşığlu, 2004). 
Bireyin, stres tepkisini tetikleyen olayı belirledikten sonra, bu olaya ilişkin değerlendirmelerini gözden geçirmesi istenmektedir. Olay olduğu an aklından neler geçmiştir? Olaya dair zihninde canlanan düşünceler nelerdir? Bu noktada amaç; uyumsuz ve gerçeğe uygun olmayan, Ellis'in deyimiyle mantıklı olmayan (irrasyonel), Beck'in deyimiyle otomatik düşünceleri yakalayabilmektir. Birey, ancak, bu düşüncelerinin, değerlendirmelerinin farkındalığını kazanarak ve bunlara meydan okuyarak tepki değişimini sağlayabilir.

Aslında, bilişsel yeniden yapılandırma tekniğinde bu sürecin not edilmesi önerilmektedir. Kişi bu kayda yaşadığı duyguyu veya stres tepkisini, bu deneyimlerin ortaya çıktığı durumu ve o an aklından geçen düşünceyi kaydetmektedir. Kayıt tutma, hem kişinin farkındalığını artırmada etkili bir yol olabilir, hem de kişi kayıt tutma yöntemi sayesinde, yaptığı değerlendirmeler ve düşünceleri üzerinde tekrar çalışma şansı elde edebilecektir (Onbaşığlu, 2004). Olayın, stresör haline gelmesini sağlayan düşünceler belirlendikten sonra, bunlara alternatif olabilecek yeni düşünceler üretmek gerekir. Karşılaşılan olay/uyarıcı hakkında, akla gelebilecek diğer düşünceler nelerdir? Bu olay/uyarıcı daha başka ne şekilde değerlendirilebilir? Amaç önceki değerlendirmenin, düşüncenin yerine geçebilecek alternatifleri yaratmaktır (Onbaşığlu, 2004). Üretilen alternatiflerin gerçeğe uygun olmasına ve kişinin aklına yatmasına dikkat edilmesi gereklidir.

Bilişsel yeniden yapılandırma tekniği uygulamasının bir sonraki basamağı; üretilen alternatiflerden, en makul ve olası görünenleri belirlemektir. Söz konusu stresörle karşılaşıldığı durumlarda, artık, makul bulunarak seçilen yeni değerlendirmeye ve düşüncelere odaklanılmaya çalışılmaktadır. Zihnin, önceki değerlendirmeler ve düşüncelerden uzak tutulması gerekmektedir. Bu değerlendirmelerin, düşüncelerin, istenen sonucu yaratması zaman ve tekrar gerektirebilir. $\mathrm{Bu}$ yeni değerlendirmelerin, düşüncelerin tekrarlanması ile eski irrasyonel düşünceler gitgide zayıflaması beklenmektedir (Onbaşıŏlu, 2004, aktaran Ata, 2014, s. 50-52).

e. Problem Çözme Tekniği: Çocukluk çağı anksiyete bozukluklarının Bilişsel Davranışçı Terapi'sinde, çocuğa yalnızca kaygıyla baş edebilmesi için gerekli davranış̧̧ı ve bilişsel tekniklerin öğretilmesi amaçlanmamakta, aynı zamanda her gün karşılaşabileceği, gerçek hayatta var olan, kaygı uyandıran ve aktif olarak üzerine gidilip çözülmesi gereken problemlerle baş edebilmesi için gerekli pratik becerilerin de öğretilmesi hedeflenmektedir.

Toplam beş basamaktan oluşan problem çözme tekniğinin ilk basamağında terapist, problemleri günlük hayatın bir parçası olarak görüp kabullenmesi ve bu problemlere verdiği kaçınma tipi dürtüsel tepkilerini daha aktif baş etme davranışlarıyla değiştirmesi yönünde çocuğu cesaretlendirmektedir. İkinci aşamada ise, çocukla problemin içe vuruk tanımlaması yapılmakta ve problem detaylı biçimde formüle edilmektedir. Tekniğin üçüncü aşamasında, problemin çözümüne ilişkin ne gibi alternatif yollar olabileceğine ilişkin bir "beyin firtınası" uygulanmakta ve olası çözümlere ilişkin liste çıkartılmaktadır. Dördüncü basamakta ise, çıkarılan bu listedeki çözüm yollarının her biri, artı ve eksi yanları ile detaylı değerlendirilmekte, bu problemin çözümü için en iyi yol seçilip karar verilmekte ve eyleme geçilmektedir. Son basamak ise, değerlendirme aşamasıdır; bu aşamada, problemin çözümüne ilişkin kullanılan yol uygulandıktan sonra sonuçlar değerlendirilmektedir (Beidas, Podell \& Kendall, 2008; Kendall \& Suveg, 2006).

Terapi esnasında, öncelikle problem çözme tekniği kuramsal olarak çocuğa anlatılmakta, ardından çocuğun sorunu dişsallaştırıp daha rahat konuşabilmesi için hipotetik örnekler üzerinden tekniğin egzersizi yapılmakta, daha sonra ise gerçek yaşam olayları ve çocuğun hayatında var olan problemler üzerinde durulmaktadır (Beidas, Podell \& Kendall, 2008; Kendall \& Suveg, 2006).

f. Ödüllendirme Teknikleri: Çocukluk çağında görülen ruhsal bozuklukların tümünün tedavisinde, Bilişsel Davranışçı Terapi 'nin değişmez terapi bileşenlerinden biri, edimsel koşullanma ilkelerine dayanan ödüllendirme yöntemleridir. Bilişsel Davranışçı Terapi 'de öğretilen ve temeli, "anksiyete azalırsa yaklaşma davranışı artar" mantığına dayanan gevşeme, maruz bırakma, model olma gibi tekniklerin aksine ödüllendirme tekniğinde, anksiyeteyi azaltmak odak noktası olmayıp, asıl amaç uygun pekiştireçlerin kullanılması yoluyla yaklaşma davranışının geliştirilmesidir. Davranış şekillendirme, olumlu pekiştireç kullanma ve sönme, anksiyete bozukluklarının tedavisinde en sık kullanılan ödüllendirme teknikleridir (Kendall \& Suveg, 2006; D’Eramo \& Francis, 2004).

Çocuklarda ödüllendirme teknikleri kullanılırken dikkat edilmesi gereken bazı noktalar bulunmaktadır. Öncelikle, her çocuk için, ihtiyaçlarına ve ilgi alanlarına göre özel bir ödül havuzu oluşturmak oldukça önemlidir. Ayrıca, bilinmektedir ki sosyal pekiştireçler, en az maddi pekiştireçler kadar çocuklar üzerinde etkili olmaktadır. Dolayısıyla, sosyal pekiştireçlerin tedavideki yeri unutulmamalıdır; seans sırasında ya da arasında sıklıkla 
kullanılmalı, bu konuda aile de bilgilendirilmelidir (D’Eramo \& Francis, 2004). Anlık ve kısa vadeli ödüller kadar, kupon ya da puan biriktirme gibi ikincil pekiştireçler de, terapi esnasında çok başvurulan ve özellikle çocuğun terapiye devamlılığını, iyileşmeye ilişkin motivasyonunu ve ödevleri eksiksiz yapmasını olumlu yönde etkileyen temel bir ödüllendirme tekniği olarak görülmektedir (Kendall \& Suveg, 2006).

g. Model Olma: Model olma, sosyal öğrenme kuramını temel alan bir kavramdır. Tekniğin rasyoneli şu şekilde açıklanmaktadır; korkulu duruma verilecek uygun tepkiler açısından model olunduğunda çocuk, korku yaratan durumla yüz yüze geldiğinde korku tepkisi vermeyecek, model aldığı ve daha işlevsel olan davranış yönünde hareket edecektir. Bu bakış açısından terapist aslında, anksiyete tepkileri açısından çocuk için iyi bir model olabilmektedir. Özellikle seans içinde yapılan rol canlandırma çalışmaları sırasında, çocuğa nasıl daha işlevsel tepkiler verebileceğine ilişkin mantıklı örnekler sunmaktadır (Beidas, Podell \& Kendall, 2008; Kendall \& Suveg, 2006).

Model olma, örtük (kaygı yaratan durumla etkili baş eden birini zihninde canlandırma), sembolik (kayg1 yaratan durumla etkili baş eden birinin bulunduğu bir film izleme), canlı (modelin kaygılı çocuğun önünde var olduğu ve çocuğun doğrudan davranışlarını gözlemlediği durum) veya katılımcı (model çocukla etkileşim içindedir ve geri bildirimler vermektedir) şeklinde gerçekleşebilmektedir (D’Eramo \& Francis, 2004).

h. Maruz Bırakma Tekniği: Çocukluk çağı anksiyete bozukluklarının süreğen ve dirençli doğasını besleyen en önemli faktör, çocuğun kaygı yaratan duruma karşı geliştirdiği kaçınma davranışıdır. Dolayısıyla, kaçınma davranışının önüne geçilmesi, sağaltım açısından Bilişsel Davranış̧̧ Terapi 'nin en önemli hedeflerinden birini oluşturmaktadır (Kendall \& Suveg, 2006).

Maruz bırakma, çocuğu korku çağrıştıran bir durumla, hayali ya da yaşantısal olarak yüz yüze getirerek, bu ve bunun gibi anksiyete yaratan olaylarla baş etmek için terapi boyunca öğrendiği becerileri uygulayıp test edebilme firsatı sağlamaktadır. Bu teknik aşamalı maruz bırakma ya da bunaltı seli (flooding) gibi farklı şekillerde uygulanabilmektedir (Beidas, Podell \& Kendall, 2008; Kendall \& Suveg, 2006).

Aşamalı maruz bırakma tekniğinde, öncelikle terapist ve çocuk anksiyeteyi tetikleyen olay ya da durumların listesini çıkartmaktadır. Ancak, listedeki olayların, en az anksiyete yaratandan en çok anksiyete yaratana doğru giden hiyerarşik bir dizilim oluşturması oldukça önemlidir (D’Eramo \& Francis, 2004). Ardından, çocuk listedeki olaylarla sırasıyla yüzleşmeye başlamaktadır. Çoğunlukla, çocuk listedeki durumlarla gerçek yaşamda karşılaşmadan önce, görüşme sırasında hayali olarak, terapistin yönlendirmesi ve kontrolüyle bu duruma maruz bırakılmaktadır. Dolayısıyla, gerçek hayatta yaşayabileceği güçlükleri ve nasıl başa çıkması gerektiğini güvenli bir ortamda prova etmiş olmaktadır. Aşamalı maruz bırakma tekniğinde unutulmaması gereken bir diğer önemli nokta, çocuğun herhangi bir basamaktaki olayla baş etmeyi daha tam olarak becerememişken, bir üst basamaktaki duruma geçilmemesi gerektiğidir (Beidas, Podell \& Kendall, 2008; Kendall \& Suveg, 2006).

Bir diğer maruz bırakma tekniği olan bunaltı selinde, çocuk anksiyete yaratan durumun kendisiyle hayali ya da yaşamsal olarak, herhangi bir hiyerarşi olmadan doğrudan karşı karşıya bırakılmaktadır. Bu tekrarlı ve uzun süren yüzleşme, çocuk anksiyetesinin belli bir seviyeye kadar düştügüünu belirtene kadar devam etmektedir.

Bunaltı seli tekniği, tepki önleme ile birlikte kullanılmaktadır; dolayısıyla, çocuğun maruz bırakma süreci bitene kadar herhangi bir kaçınma davranışı uygulaması engellenmektedir. Ancak, bunaltı seli, aşamalı maruz bırakma tekniğine göre kişide oldukça yoğun bir anksiyeteye sebep olduğu için, pratikte çocuk hastalarda kullanım alanı oldukça sınırlıdır. Uygulanacağı zaman ise, çocuğun tekniğin rasyonelini iyi anladığından ve yapılacak uygulamayı detaylı biçimde bildiğinden emin olmalıdır; bu detaylı bilgilendirme sağaltımın etkililiği açısından oldukça önemlidir (D’Eramo \& Francis, 2004, aktaran Tok, 2014, s.53-57).

\section{Çocukluk Çağı Anksiyete Bozukluklarının Tedavisinde Kullanılan Bilişsel Davranışçı Terapi Temelli Yapılandırılmış Terapi Programı Örnekleri}


Bilişsel Davranışçı Terapi 'nin, ruh sağlığı alanında bir sağaltım tekniği olarak kullanılmaya başlanması 1970'li yıllara dayansa da çocukluk çağı anksiyete bozukluğunun tedavisi için bir seçenek haline gelmesi yaklaşık 20 yıllık bir geçmişe sahiptir. Bu alandaki ilk yapılandırılmış Bilişsel Davranışçı Terapi programının, Kendall'ın oluşturduğu "Coping Cat (Baş Eden Kedi)" programıdır. Kendall'in 1990 yılında yayınlamış olduğu çalışma kitabı (workbook), 8-13 yaş arası çocuklara yönelik olarak tasarlınmış ve ayrılma anksiyetesi bozukluğu, yaygın anksiyete bozukluğu, panik bozukluk ve agorafobi, özgül fobi ile sosyal fobinin tedavisinde kullanılacak bir psikolojik müdahale programı olarak düşünülmüştür (Kendall, Chu, Gifford, Hayes \& Nauta, 1998). Çocukluk çağı anksiyete bozukluğunun tedavisinde kullanılan ve daha önceki bölümde özetlenen temel Bilişsel Davranışçı Terapi tekniklerini içinde barındıran bu programın iskeleti, toplam dört ana basamaktan oluşmaktadır.

Terapinin ilk basamağında psikoeğitim ile başlanmakta ve anksiyetenin yarattığı duygusal/bedensel belirtilerin çocuk tarafindan fark edilmesi amaçlanmaktadır. İkinci aşamada, anksiyete yaratan düşünce, inanç ve iç konuşmaların yakalanması hedeflenmektedir. Bu işlevsel olmayan düşünce biçimlerini fark eden çocuk, terapinin üçüncü aşamasında gevşeme, bilişsel yeniden yapılandırma aracıllğıyla iç konuşmayı değiştirme ve problem çözme becerilerini kullanarak bu olumsuz düşüncelerin yarattığı anksiyete ile baş etmeyi öğrenmeye başlamaktadır. Son aşamada ise, maruz bırakma tekniği kullanılmakta ve çocuk korku yaratan olay/durumlarla aşamalı olarak yüz yüze bırakılmaktadır. Bu süreçte çocuk, şimdiye kadar öğrendiği baş etme becerilerini kullanmakta ve sürecin sonucunda baş etmeye ilişkin sonuçları değerlendirilerek kendini ödüllendirmektedir (Kendall \& Hedtke, 2006a; Kendall \& Hedtke, 2006b).

$\mathrm{Bu}$ terapi planının çocuklar tarafından daha kolay hatırlanabilmesi için, her bir harfi bir basamağı ifade eden "FEAR Plan (Korku Planı)" akrostişi kullanılmıştır. F harfi "Feeling frightened?", E harfi "Expecting bad things to happen?", A harfi "Attitudes and actions that can help" ve R harfi "Results and rewards" anlamlarına gelmektedir. Seansların sonunda, o hafta öğrenilen tekniğe ilişkin uygun ev ödevleri verilmekte ve çocuk bu ödevleri yaptı̆̆ında kasasında puan birikmektedir. Bu puanlar belirli aralıklarla, çocuğun önceden yapmış olduğu ödül listesindeki ödüllere dönüşmektedir (Kendall \& Hedtke, 2006a; Kendall \& Hedtke, 2006b).

Sonuç olarak, 14'ü çocuk ve 2'si aile görüşmesi olmak üzere toplam 16 seanstan oluşan bu programın aile görüşmeleri, çocuğun üçüncü ve sekizinci seanslarından sonra gerçekleştirilmektedir. Aile görüşmelerinde temel olarak, çocukluk çağı anksiyete bozukluklarının doğası hakkında psikoeğitime, terapi programının kısa tanıtımına, anksiyeteyi tetikleyen ya da yatıştıran ebeveyn tutumlarına, etkili ebeveynlik yöntemlerine ve aile içi iletişim becerilerine, özellikle terapide verilen ev ödevlerinin yapılması ve maruz bırakma tekniğinin uygulanması sürecinde ailelerin çocuklarına nasıl yardım etmeleri gerektiğine değinilmektedir (Kendall \& Hedtke, 2006a; Kendall \& Hedtke, 2006b).

Kendall ve ekibinin yürüttükleri çok sayıda kontrollü ve izlemli etkililik çalışmaları sonucunda, Coping Cat programı çocukluk çağı anksiyete bozukluğunun tedavisinde yaygın biçimde kullanılmaya başlanmış ve farklı ülkelerdeki araştırmacılar tarafindan o ülkelerin dillerine çevrilerek pratikte kullanılmaya başlanmıştır.

Avustralya'nın “Coping Kuala (Baş Eden Kuala)” programı (Barrett, Dadds \& Rapee, 1991) ile Kanada'nın “Coping Bear (Baş Eden Ayı)"programı (Scapillato \& Mendlowitz, 1993) bu uyarlamaların en bilinenleridir.

Çocukluk çağı içe yönelim bozukluklarının (depresyon ile obsesif kompülsif bozukluk ve travma sonrası stres bozukluğu dışındaki tüm anksiyete bozuklukları) tedavisi için Barrett, Lowry-Webster ve Turner tarafindan 2000 yılında, ilk olarak grup formatında geliştirilen "FRIENDS" programı bir diğer yapılandırılmış Bilişsel Davranışçı Terapi programı olarak bilinmektedir (Barrett, Lowry-Webster \&Turner, 2000a; Barrett, Lowry-Webster \& Turner, 2000b). FRIENDS programı, Coping Cat ve Coping Kuala gibi alanda öncü kabul edilen terapi el kitapları temel alınarak oluşturulmuştur.

Tedavi rasyoneli ve kullanılan temel teknikler (duygusal/fizyolojik farkındalığın kazandırılarak gevşeme egzersizleri gibi baş etme tekniklerinin öğretildiği psikoeğitim; bilişsel yeniden yapılandırma ve olumlu iç konuşmaların inşa edilmesi gibi bilişsel beceriler; problem çözme becerisi ve kendini ödüllendirme gibi davranışsal beceriler; kaçma/kaçınma/güvenlik arama davranışlarını ortadan kaldırmak ya da en aza indirmek için maruz bırakma tekniği) oldukça benzer olmakla birlikte, bu program diğer terapi programlarına göre görece daha kısa bir formata sahip olup, haftada bir yürütülen toplam 10 seanstan oluşmaktadır. Grup formatında seansların süresi 90 dakika olarak belirlenmiş olup, daha sonra çıkan programın bireysel formatında her bir seans 60 dakika olarak tasarlanmıştır. 
Diğer terapi programlarından bir diğer farkı ise, anksiyete belirtilerine odaklandığ 1 kadar depresif belirtilere de odaklanıyor olmasıdır. Çocuk seanslarına ek olarak, çocukluk çağı içe yönelim bozuklukları hakkında psikoeğitim, FRIENDS programının tanıtımı ve etkili ebeveyn yaklaşımları konularını kapsayan toplam 4 seanslık aile görüşmesi de programa eklenmektedir (Siu, 2007).

Sosyal fobinin tedavisinde kullanılmak üzere Beidel, Turner ve Morris tarafından 1998 yılında geliştirilen Bilişsel Davranışçı Terapi temelli bir tedavi programı ise "Çocuklar İçin Sosyal Etkililik Terapisi (Social Effectiveness Therapy for Children-SET-C)" isimli programdır. 8-12 yaş arası çocuklara uygun olarak geliştirilen bu program, aynı haftalarda eş zamanlı olarak yürütülen 12 bireysel ve 12 grup seansından oluşmaktadır (bireysel seansların her biri 60 dakika, grup seanslarının her biri 90 dakika). Bireysel seanslarda hayali ve yaşantısal maruz bırakma çalışmaları yapılırken, grup seanslarında sosyal beceri eğitimi ve uygulamaları, bilişsel yeniden yapılandırma egzersizleri ile sosyal anksiyete hakkında psikoeğitime yer verilmektedir (Beidel, Turner \& Morris,2000).

Çocukluk çağı anksiyete bozukluğunun sağaltımında kullanılmak için tasarlanan bir diğer yapılandırılmış terapi programı, Hollanda'da Bögels tarafindan 2008 yılında geliştirilmiş "Düşün+Yap=Korkma (Thinking+Doing=Daring-TDD)" isimli bireysel Bilişsel Davranışçı Terapi programıdır. Etkililiği kanıtlanmış Coping Cat, Friends gibi programları model alınarak hazırlanan bu el kitabı, toplam 20 seanstan oluşan ve temel Bilişsel Davranışçı Terapi tekniklerini içeren (psikoeğitim, gevşeme teknikleri, bilişsel yeniden yapılandırma, ödüllendirme, model olma ve maruz bırakma teknikleri) çocuk seansları ile toplam 3 seanstan oluşan ve anksiyete yaratan durumla karşılaştıklarında çocuklarıyla nasıl doğru iletişime geçeceklerini, onları motive edip destekleyeceklerini anlatan ebeveyn seanslarından oluşmaktadır.

Bir diğer yapılandırılmış Bilişsel Davranışçı Terapi temelli program ise, Türkiye'de kullanılmak üzere geliştirilen "Korku Avcısı" programıdır (Sorias vd., 2009; Sorias, Bildik, Tekinsav-Sütcü ve Aydın, 2009). Çocuk için yürütülecek terapi seanslarında kullanılmak üzere hazırlanan bir çalışma kitabı ile bir terapist el kitabı bulunan bu program, 8-14 yaşları arasında bulunan ve ayrılma anksiyetesi bozukluğu, yaygın anksiyete bozukluğu, özgül fobi ya da sosyal fobi tanısı almış çocukları hedef almaktadır. Obsesif kompülsif bozukluk ve travma sonrası stres bozukluğu gibi, kendine has özellikler taşıyan ve diğer anksiyete bozukluklarının tedavisinde kullanılan tekniklerden daha farklı yöntemlerle sağaltımı düzenlenen anksiyete bozuklukları için özel olarak geliştirilen terapi programı el kitaplarının bulunduğu gözlenmiştir. Okul temelli olarak hazırlanan ve grup formatında olan "Cool Kids" programı da çocukluk çağı anksiyete bozukluklarının tedavisi için geliştirilmiştir (Lyneham, Abbott, Wignall \& Rapee, 2003, aktatan. Tok, 2014, ss. 57-61).

\section{Bilişsel Davranış Değiştirmenin Kullanıldığı Problem Alanları}

Bilişsel davranış değiştirme; saldırganlık, kaygı, panik hastalığı, madde bağımlılığı, şizofreni, çift kutuplu rahatsızlık, sınır kişilik bozukluğu, depresyon, zayıf sosyal problem çözme, sınırlı otokontrol gibi birçok problemi çözerken kullanılmaktadır (Kendall, 1993; Larson \& Lochman, 2002; Leahy \& Beck, 1988; Mayer, Lochman \& Acker, 2005). Bu teknik ayrıca otizmli bireylerde de başarılı bir şekilde uygulanmaktadır (Quinn, Swaggart, \& Myles, 1994). Özel gereksinimli çocukların eğitiminde de kullanılmaktadır. Otizmli bireylerde, Asberger sendromlularda, DEHB'nda, Hafif düzeyde zihinsel yetersizliği olanlarda, Uyumsuz çocuklarda kullanılmaktadır (Kendall,1993; Larson \& Lochman, 2002; Leahy \& Beck, 1988; Lochman \& Acker,2005; Quinn, Swaggart \& Myles, 1994).

\section{Uygulama Basamakları}

1. Modelleme: Öğretmen bir problemi çözerken, kullandığı strateji basamaklarını sesli bir şekilde ifade eder.

2. Deneme: Modellemeden sonra, gerektiğinde yardım ederek öğretmen öğrencinin sürecini denemeye başlar. Bu süreç, öğrenci en az yardımla problemi çözene (görevi gerçekleştirene) kadar günlük olarak devam ettirilir. Öğretmen veri toplamaya ve süreci izlemeye öğrenci önceden belirlenen hedefleri başarana kadar devam eder.

3. Kendini Kaydetme: Öğrenci öğretmen kontrolünde başardıktan sonra, bir öz-izleme çizelgesi oluşturur ve onu doldurmaya başlar veya hedef davranış gerçekleştiğinde onu kendi kendine not etmeye başlar.

4. Kendini Ödüllendirme: İstenen basamaklar ve öz- izleme tamamlandıktan sonra, öğrenci tercih ettiği pekiştirenle kendi kendini ödüllendirir. Bu dört basamak klasik otizmli bireylerde öğretim basamağı olarak ifade edilmiştir. 
Ayrıca ileri düzey (yüksek işlevli) otizmliler için üç öğretim basamağı önerilmiştir:

1.Öz- İzleme: Öğrenci bir ses kaydı dinler; ses kaydını duyduğunda, kendi kendine sorar: "Dikkatimi veriyor muyum?".

2.Kendini Kaydetme: Öğrenci hemen kendini, dikkat edip etmediğini değerlendirir. Eğer dikkatini veriyorsa "evet" $\mathrm{i}$ işaretler, ilgisiz ise "hayır" 1 işaretler.

3.Kendini Ödüllendirme: Öğrenci dikkatini verdiği davranışlar için kendi "aferin bana" diyerek kendini ödüllendirir. Eğer öğrenci ilgisiz ise, kendi kendine sessizce "iş başına" diyerek uyarır ve hemen işe kaldığ 1 yerden devam eder (Quinn vd. 1994).

\section{Örnek Durumlar}

Norton 15 yaşında asperger sendromu olan bir çocuk: Norton soysal kısıtlamaları ve kuralları anlamada zorlanıyor. Çoğu zaman sosyal yargılarında başkalarını rahatsız eden hatalar yapıyor. Mesela, geleneksel selamlama merasimini insanları kucaklayarak ve onları öperek es geçiyor.

Norton'un öğretmeni, Bayan Williams, Norton için arkadaşları ve akrabalarını selamlama yollarını içeren bir problem çözme ölçeği hazırlamaya karar verdi. Öğretmeni ve Norton selamla yollarını farklı kişilere göre düzenlediler: Örneğin, arkadaşlarına "merhaba" deme, maçtan sonra basket koçunun elini sıkma veya onunla beşlik çakma (high five= çak bir beşlik). Ayrıca öğretmeni Norton'a kendi selamlaşmalarını değerlendirmesi için günlük tutmayı da öğretti.

Palmen, Didden ve Arts (2008) tarafindan 9 ileri düzeyde otizmli (yüksek işlevli otizmliler) genç ile geri dönüt verilen ve öz-yönetim yapılan küçük grup çalışmalarının soru sorma becerisi üzerine etkisi araştırılmıştır. Yapılan çalışmadan sonra bütün katılımcıların soru sormalarında istatiksel olarak anlamlı bir gelişme gözlemlenmiştir. Sofronoff, Attwood, Hinton ve Levin'in (2007) çalışmalarında bilişsel davranış değiştirme tekniğinin "AS”li çocuklarda öfke kontrolüne etkisi değerlendirilmiştir. 45 çocuk ve aile rastgele kontrol grubuna veya deney grubunu atanmıştır. Sonuçlar bilişsel davranış değiştirme tekniğinin pozitif etkisini ortaya koymaktadır.

Ben-Arieh ve Myles (2003) tarafından bilişsel davranış değiştirme tekniğinin 6 yaşındaki "AS”li bir çocukta etkisi araştırılmıştır. Çocuğa verilen göreve dikkatini arttırmada kullanması için stratejiler öğretilmiş ve bu arada yavaş yavaş yetişkin uyarıları azaltılmıştır. Stratejileri kullanmaya başlaması ile birlikte çocukta dikkatini verme davranışlarının görülmeye başlandığı tespit edilmiştir.

Barry ve Singer (2001)'nin araştırmalarında, hekim tarafından uygulanan davranış değişikliği için beceri geliştirme ve davranış değişikliği için hekim gözetiminde öz demetleme uygulamalarının kardeşlerine karşı saldırgan davranışlar gösteren 10 yaşındaki bir çocuğa etkisi araştırılmış; saldırgan davranışlarda azalmayı gösterirken, kardeşleriyle zaman geçirme süresinde ve istenilen davranışların gözlemlenme oranında artış gözlenmiştir.

Callahan ve Rademacher (1999)'nın araştırmalarında, öz-yönetim strateji ve pekiştirme kullanımının 2. Sınıf otizmli bir öğrencinin derse dikkatini verme davranışlarına etkisi araştırılmış, öğrencinin derse dikkatini vermesinin istatiksel olarak anlamlı şekilde arttığ 1 gözlemlenmiştir. Ayrıca öğrencinin bağımsız akademik işlevselliği ve tek başına davranışlarında gelişme gözlemlenmiştir.

Shearer, Kohler, Buchan ve McCullough (1996)'nin çalışmalarında öz-izlemenin 3 tane otistik okul öncesi öğrencisinin aktivitelere katılımı ve sosyal etkileşimi üzerine etkisini araştırılmış, yetişkin ve çocuğun kendi izlemesi, diğer otistik arkadaşlarıyla etkileşimini eşit seviyede geliştirmiştir. Tekniğin uygulanmasından sonra çocuklarda bağımsız etkileşimler gözlenmeye devam etmiştir. Çocuklar çeşitli seviyelerde kendi öz-izlemelerinde tutarlılık göstermişlerdir.

Strain, Kohler, Storey ve Danko (1994), tarafindan yapılan üç otizmli erkek çocuk, öz-izlemenin etkisinin araştırıldığı bu araştırmada ilk olarak, öz-izleme her üç çocuğun akranlarıyla ve kardeşleriyle olan etkileşiminin geliştiği; ikinci olarak, okul ve ev süreçlerinin ayrı ayrı çocukların bazı sosyal davranışlarına etkili olduğu; son olarak, yetişkin uyarı ve pekiştirmeleri hem okulda hem de ev ortamlarında azaldığı tesbit edilmiştir.

Koegel, Koegel, Hurley ve Frea'in (1992) çalışmasında, öz-yönetim tekniğinin çocukların başkalarından (okul, ev, çevre) gelen sözel etkileşimlere verdikleri cevaba etkisi araştırılmış, farklı ortamlarda çocukların başkalarına yanıt vermek için öz-yönetimin etkili bir yöntem olabileceği, istemeyen davranışların başka bir yönteme ihtiyaç duyulmadan azaltılabileceği saptanmıştır. 
Koegel ve Koegel (1990), tarafindan yapılan çalışmada 4 otizmli çocuğun öz-yönetimi öğrenerek basmakalıp davranışlarını azaltıp azaltamayacaklarını araştırılmıştır, her çocuğun öz-yönetim tekniğinin çok iyi bir şekilde öğrenip basmakalıp davranışlarını azalttıkları ve bu tutumlarını daha sonraki ortamlara da taşıdıkları ortaya konulmuştur.

\section{Psikolojik Danışma ve Psikoterapi Alanında}

Bilişsel terapinin anahtar bakış1; depresyon, kaygı ve öfkenin, bilişsel çarpıtmaların tekrarlayan örüntülerinin sonucu olduğu biçimindedir. Bilişsel çarpıtmalar (olumsuz inançlar); zihin okuma, geleceği söyleme, felaketleştirme etiketleme, olumlu olayları saymama, olumsuz seçicilik, aşırı genelleme, ikili düşünme, dayatmalar, kişiselleştirme, suçlama, adaletsiz kıyaslamalar, pişmanlık eğilimi, ya olursa düşüncesi, duygusal çıkarsama, yanlışlanamama, yargılamaya odaklanma şeklinde sıralanmaktadır (Leahy, çev: Vardareli \& Türkçapar, 2010).

Bilişsel Davranışçı Terapi bu ve benzeri olumsuz düşüncelerden kurtulması konusunda bireye profesyonel yardım sunar. Olumsuz düşüncelerden arındırmada yararlanılan en yaygın terapiler; Akılcı Duygusal Terapi (ADT), Gerçeklik Terapisi ve Sosyal Bilişsel Kuram ve Bilişsel Terapi'dir. Bilişsel terapiler yukarıda ifade edilen problem alanlarının yanı sıra genelleşmiş anksiyete bozukluğu, hipokondriya, travma sonrası stres bozukluğu, evlilik çatışması, cinsel işlev bozuklukları, sınır durum (Borderline) kişilik bozukluğu, psikotik bozukluk, bedensel engellilik gibi insanı ilgilendiren birçok problemle baş etmede kullanılabilir (Leahy çev: Hacak, Macit \& Özpilavc1,2007)

Elmacı (2008), araştırması kapsamında, deney grubunda bulunan deneklere 10 oturumdan oluşan Bilişseldavranış̧̧ı yaklaşıma dayalı grupla psikolojik danışma oturumları gerçekleştirilmiştir. Deney grubuyla paralel zaman diliminde kontrol grubunda bulunan deneklerle de 3 oturumdan oluşan etkinlik gerçekleştirilmiştir. Ön- test, son- test ve izleme ölçümlerinden elde edilen verilere uygulanan istatistiksel analiz bulgularınca Bilişsel-davranışçı yaklaşıma dayalı grupla psikolojik danışmanın, ergenlerin korkularının azaltılmasında etkili olduğunu ve bu etkinin belirli bir süre devam ettiğini göstermektedir.

Heiman (2002), vajinismus tedavisinde psikolojik müdahalelerin yetersiz olduğunu; psikoterapötik müdahalelerin yalnızca hafif vajinismus vak'alarında ise, yarayabileceğini öne sürmüştür. Benzer şekilde pek çok yazar; bireysel terapilerin uzun, pahalı ve bazı vakalar için yararsız olduğunu ve davranışsal - tıbbi tekniklerde (dilatörlerin kullanılması, maruz bırakma, aşamalı kas gevşetme gibi) yarar sağlanamadığı takdirde hastaların bireysel ya da cinsel terapilere yönlendirilmeleri gerektiğini söylemektedir (Nancy \& Phillips 2000, Shafik \& El-Sibai 2000, aktaran Özdel, 2009, s. 13).

Hiçdurmaz (2010), araştırmasında grup danışmanlığı sonunda öğrencilerin, Kısa Semptom Envanteri olumsuz benlik ve diğer alt ölçekleri ile Otomatik Düşünceler Ölçeği puan ortalamaları son ölçüm ve izleme ölçümünde istatistiksel olarak anlamlı düzeyde giderek azalmıştır $(\mathrm{p}<0.05)$. Stresle Başa Çıkma Tarzları Ölçeği'nde "kendine güvenli” ve "iyimser" yaklaşım alt ölçeği puan ortalamaları istatistiksel olarak anlamlı düzeyde her ölçümde artmış, "çaresiz" ve "boyun eğici" yaklaşım puan ortalamaları ise azalmıştır $(p<0.05)$. "Sosyal destek arama" alt ölçeğinin danışmanlık sonunda istatistiksel olarak anlamlı düzeyde yükselen puan ortalaması, izleme ölçümünde düşmüştür $(\mathrm{p}<0.05)$.

Özü (2010)'nün araştırmadan elde edilen bulgulara göre, Stresle Başa Çıkma Becerileri Eğitim Programı"na katılan bireylerin (deney grubu) genel stres düzeylerinde, bu programa katılmayan bireylerin (plasebo ve kontrol grupları) genel stres düzeylerine göre anlamlı düzeyde bir azalma olmuştur. Ayrıca Stresle Başa Çıkma Becerileri Eğitim Programı' na katılan bireylerin (deney grubu) genel kaygı düzeylerinde, bu programa katılmayan bireylerin (plasebo ve kontrol grupları) genel kaygı düzeylerine göre anlamlı düzeyde bir azalma olmuştur. Yine Stresle Başa Çıkma Becerileri Eğitim Programı' na katılan bireylerin (deney grubu) genel iyilik hali düzeylerinde, bu programa katılmayan bireylerin (plasebo ve kontrol grupları) genel iyilik hali düzeylerine göre anlamlı düzeyde bir artış olmuştur.

Sapmaz (2011), bilişsel davranış̧̧ı yaklaşım odaklı grupla psikolojik danışmanın sosyal anksiyete, sosyal korku, sosyal kaçınma, red duyarlılığı ve kişilerarası duyarlılık düzeylerini azaltmada etkili olduğunu ve bu etkinin üç aylık izleme sonunda da kalıcılığını korumakla birlikte artarak devam ettiğini ortaya koymuştur. Pehlivan (2011), bilişsel davranışçı yaklaşıma dayalı psiko-eğitim programının annelerin problem çözme beceri düzeylerini, iletişim beceri düzeylerini, evlilik doyum düzeylerini ve iyi oluş düzeylerini arttırdığını tesbit etmiştir. Sarısoy (2011), bilişsel 
davranışçı yaklaşıma dayalı grupla psikolojik danışma oturumlarına katılan üniversite öğrencilerinin Obsesif Kompülsif Belirti, Kişilerarası Duyarlılık Belirti, Depresif Belirti, Kaygı, Paranoid Düşünce Belirti, Ek Ruhsal Belirti düzeylerinin azaldığını ve bu etkinin üç ay boyunca devam ettiğini ortaya koymuştur. Ay (2018), kanserli çocuğu olan ebeveynlere verilen bilişsel davranışçı yaklaşım temelli psiko-eğitimin stresle başa çıkma tarzlarını artırmada, umutsuzluk düzeylerini azaltmada etkili olduğunu belirlemiştir.

Avcı (2017)'nın çalışmasında yapılan analizler madde bağımlılı̆̆ tedavisi almış deney grubu katılımcılarında bilişsel davranış̧̧ grup terapisi sonrası madde kullanma isteği ve madde kullanma olasıllğı puanlarında anlamlı bir düşüş olduğu, kontrol grubunda ise anlamlı bir değişim olmadığ bulgulanmıştır. Relapsla ilişkili olduğu düşünülen değişkenler incelendiğinde, deney grubunda bilişsel davranışçı grup terapisi sonrası akılcı olmayan inanç ve duygu düzenleme güçlügü̈ puanlarında anlamlı bir azalma ve psikolojik dayanıklılığa ilişkin yılmazlık ölçeğinden aldıkları puanlarda anlamlı bir artış olduğu görülmüştür. Kontrol grubunda ise ön test ve son test arasında hiçbir değişkende anlamlı bir değişim bulunmamıştır. Çalışmada sadece öz-yeterlik değişkeninde çalışma öncesi ve sonrası deney ve kontrol grupları arasında anlamlı bir fark bulunamamıştır. Ersanlı (2007), çalışmasında Bilişsel-davranışçı yaklaşıma dayalı evlilik ilişkisini geliştirme programı evlilerin evlilik ilişkilerinde çaresizlik ve sevilemezlik inançlarıyla baş etmelerini anlamlı olarak yükseltmektedir sonucuna ulaşmıştır.

Kurtoğlu (2013)'nun araştırmasından elde edilen bulgular, bilişsel davranışçı yaklaşıma dayalı psiko-eğitim programına katılan öğrencilerin duygusal yılmazlık düzeylerinin, bu programa katılmayan öğrencilerin duygusal yılmazlık düzeylerinden anlamlı düzeyde yüksek olduğunu göstermiştir. Bilişsel davranışçı yaklaşıma dayalı psikoeğitim programına katılan öğrencilerin sosyal beceri-okula uyum ve benlik saygısı düzeyleri, plasebo grubuna katılan öğrencilerin sosyal beceri-okula uyum ve benlik saygısı düzeylerine göre anlamlı düzeyde yüksektir. Ancak, deney grubuna katılan öğrenciler ile kontrol grubuna katılan öğrenciler arasında sosyal beceri-okula uyum ve benlik saygıs1 düzeyleri bakımından anlamlı düzeyde bir fark bulunmamıştır.

Buğa (2015)'nın araştırmasında yapılan analizler sonucunda, hem web tabanlı interaktif hem de geleneksel psiko-eğitim programlarında yer alan deneklerin bilişsel hatalarının uygulama sonrasında azaldığı ve izleme dönemlerinde de devam ettiği; Web tabanlı interaktif programda yer alan deneklerin psikolojik belirtilerinin de uygulama sonrasında azaldığı ve izleme dönemlerinde de devam ettiği; geleneksel psiko-eğitim programında yer alan deneklerin psikolojik belirtileri açısından uygulama öncesi ve sonrasında herhangi bir değişiklik olmadığı sonucuna ulaşılmıştır. Elde edilen bulgular; araştırmacı tarafından geliştirilen web tabanlı interaktif psiko-eğitim programının çocukların bilişsel hatalarını ve psikolojik belirtilerini azaltmada etkili olduğunu göstermektedir.

Balcı (2014)'nın çalışması sonucunda Bilişsel Davranışçı Terapi ile tedavi edilen vajinismuslu kadınlarda ve eşlerinde tedavi öncesine göre tedavi sonunda benlik saygısı, öz-yeterlilik, yaşam kalitesi ve cinsel doyum düzeylerinde olumlu yönde değişimler olduğu görülmüştür. Bu olumlu değişimler semptomun iyileşmesine ve/veya uygulanan tedavi biçimine bağlı olarak ortaya çıkmış olabilir. Değişimin neye bağlı olarak ortaya çıtığını anlamak için Bilişsel Davranışçı Terapi "yi diğer tedavi yöntemleriyle karşılaştıran çalışmalar yapılmalıdır.

Gökkaya (2015)'nın araştırmasından elde edilen niteliksel ve niceliksel, tüm bulgular değerlendirildiğinde, zorbalık eğilimini azaltmaya yönelik hazırlanmış olan Bilişsel Davranışçı müdahale programının, zorbalığa ilişkin bilişleri değiştirmede ve zorbalık davranışlarını azaltmada etkili bir müdahale yöntemi olduğunu söylemek mümkündür. Ancak plasebo kontrol grubunun da zorbalık davranışını azaltmada benzer bir etkinliğinin olduğu görülmektedir. Uçar (2014), bilişsel davranışçı tekniklere dayalı doğum korkusuyla başetme eğitim programının gebelerin doğum korkusunu azalttığını ve doğum sürecini olumlu etkilediğini belirlemiştir.

\section{Uygulama örneği: Depresyon Tedavisinde Bilişsel Davranış̧̨ı Terapi ile Motivasyonel Görüşme Entegrasyonunun Hazırlanmasi}

(Heather A. F. (2011). Setting the stage for the integration of motivational intervewing with cognitive behavioral therapy in the treatment of depression. Cognitive and Behavioral Pratice, 18(1), 46-54. doi:10.1016/j.cbpra.2009.09.006 referanslı kaynaktan aynen aktarılmıştır).

\section{Özet}

Unipolar depresyon, dünyada en maliyetli ve bireyi en çok engelleyen tıbbi hastalıklardan biridir (Lancet Global Mental Health Group vd., 2007; Moussavi vd., 2007). Depresyon tedavisinde yaygın olarak çalışılmış ve 
öğretilmiş psikoterapik tedavi olan Bilişsel Davranış̧̧ı Terapi, tavsiye edilen kanıta dayalı tedaviler arasında yer almaktadır. Her ne kadar Bilişsel Davranışçı Terapi ve diğer tedavi yöntemleri oldukça etkili olsalar da depresyon yaşayan birçok birey tedaviye tamamıyla yanıt vermemektedir. Dolayısıyla bireylerin hayatları boyunca hastalıkları nüksedebilmekte ve istenmeyen sonuçlarla karşı karşıya kalabilmektedir. Bu makale, Bilişsel Davranışçı Terapi sonuçlarını geliştirmenin olası bir yöntemi olarak Motivasyonel Görüşmenin entegrasyonunu el almaktadır. Motivasyonel Görüşme, klinik sonuçlarla ilişkilendirilen karşıllklı temel terapist-hasta etmenlerini ve tedavide motivasyonun rolünü irdeleyen kanıta dayalı bir yaklaşım sağlamaktadır. Bu itibarla Motivasyonel Görüşme; terapötik ittifakın geliştirilmesi, motivasyon, ve özelliklede tedaviye katılımı etkileyen ikilem(direnç)i irdeleme ve tedavinin (ödev gibi) çeşitli yönlerini zihinde tutma ve bağl1lık gibi Bilişsel Davranışçı Terapi 'nin belirli yönleriyle uyum içinde işleyebilir. Bilişsel Davranışçı Terapi eğitimi alan klinisyenler için Motivasyonel Görüşme ayrıca; empati, işbirliği ve hasta merkezli aktif dinleme gibi temel psikoterapik becerileri öğrenmek için bir model sağlayabilmektedir. Depresyon tedavilerinin etkinliğini ilerletmenin zorunluluğundan dolayı, tedavinin genel etkinliğinin Motivasyonel Görüşme ve Bilişsel Davranışçı Terapi Birleşmesi ile ne kadar gelişeceği klinik araştırma yapılmasını gerektirmektedir.

Geçtiğimiz son birkaç on yıl içinde, depresyonun niteliği ve tedavisi hakkında çok şey aydınlığa kavuştu. Dünya Sağlık Örgütü'nün iki büyük ölçekli raporu, depresyona karşı dünya genelinde tıbbi bir yetersizliği belgelemektedir. Dolayısıyla gelişmiş tanı ve tedavi, küresel bağlamda kamu sağlığı açısından öncelik teşkil etmektedir (Chisholm vd., 2007; Moussavi vd., 2007). Unipolar depresyon için oldukça etkili olan tedavilerin geliştirilmesi ve araştırılması alanlarında da gelişme kaydedilmiştir. Tedavi görmeyen ve yetersiz tedavi gören hastalarla karşılaştırıldıklarında uygun depresyon tedavisi alan bireyler, rahatsızlıklarını daha kısa sürede atlatmakta ve hastalıklarının tekrarlanma olasılığı daha az olmakla beraber depresyon-arası daha uzun sağlıklı yaşam süresine sahiptirler (Frank vd., 1990; Segal vd., 2002). Unipolar depresyonun gerek ilaç tedavisi gerekse psikoterapisi, deneysel olarak desteklenmiş ve en iyi klinik uygulamalarının bir parçası olarak kabul görmüştür (American Psychiatric Association [APA], 2000; ayrıca makale tahlili için bkz. Hollon, Thase \& Markowitz, 2002,). Bilişsel Davranışçı Terapi depresyon için en çok çalışılan, yaygın olan ve öğretilen kitaplaşmış psikoterapiler arasında yer almaktadır. Depresyonun remisyonundaki etkililiği kanıtlanmış olmasına karşın Bilişsel Davranış̧ı Terapi tedavisi gören çok sayıda hasta tedaviye katılım göstermemekte, kendini adamamakta ve/veya yanıt vermemektedir (American Psychiatric Association, 2000; De Rubeis vd., 2005).

$\mathrm{Bu}$ makale klinik araştırmalarını teşvik etmek ve psikoterapist eğitim modellerinin iyileştirilmesi için Bilişsel Davranış̧̧ Terapi depresyon tedavisi sonuçlarını geliştirebilecek olası bir yöntemin kullanışl1lığını araştırmaktadır. Özellikle de hasta katılımını ve bağlılığını artıran, tedaviye direnci azaltan, motivasyonu yükselten, belirli davranış değişikliğini geliştirme alanlarında kanıta dayalı bir yaklaşım olan Motivasyonel Görüşme depresyon tedavisinde bütün sonuçların geliştirilmesinde Bilişsel Davranışçı Terapi ile potansiyel bir sinerji içerisinde sunulacaktır. Makalede sinerji, iki tedavi arasındaki "işbirliği içerisinde faaliyet" olarak kullanılmıştır. Yakın zamanda yayınladıkları bölümlerinde Arkowitz ve Burke (2008), Bilişsel Davranışçı Terapi 'nin her aşamasında faydalanılabilecek bütünleştirici bir sistem olan Motivasyonel Görüşme'nin ana hatlarını özetlemiştir. Motivasyonel Görüşme özellikle; motivasyonu yükseltmek, tedaviye direnci azaltmak ve bir husustaki (katılım, bağl1lık ve/veya tedavi sonucu davranış değişikliği gibi) ikilemi ortadan kaldırmak için Bilişsel Davranış̧̧ı Terapi 'nin herhangi bir aşamasında uyum içinde birleştirilebilir (Arkowitz ve Burke; Arkowitz \& Westra, 2004).

$\mathrm{Bu}$ tasarı, Kombine Davranışsal Müdahale'nin (KDM) alkol kullanım bozuklukları tedavisinde kullanılmak üzere (ailesel ve sosyal/toplumsal ilgi, kendine yardım grupları, bireysel tedavi yaklaşımının yanı sıra) Motivasyonel Görüşme ve bilişsel-davranışsal beceri eğitimi de dahil olmak üzere çeşitli kanıta dayalı unsurlarının birleştirildiği kombine araştırmadaki (Miller, 2004) kullanılış biçimine benzerlik göstermektedir. Bahsedilen araştırmada tedavi entegrasyonu, Motivasyonel Görüşme terapötik yönteminden Bilişsel Davranışçı Terapi 'sinin tüm aşamalarında faydalanılması olarak kullanılmıştır. Psikoterapi entegrasyonu; başka bir çalışmada "tek alan yaklaşımların yetersizliklerini aşarak diğer yaklaşımlardan nasıl faydalanılabileceğini anlamak amacıyla gerçekleştirilen ve farklı teori ve tekniklere açık olma özelliği gösteren çeşitli teşebbüsler” olarak açıça tanımlanmıştır (Arkowitz, 1997, s. 228). Bilişsel Davranış̧̧ı Terapi ile Motivasyonel Görüşme entegrasyonu ifadesiyle Bilişsel Davranışçı Terapi 
terapistlerinin Motivasyonel Görüşme'nin (motivasyonu ve ikilemi irdelemek, karşı koymayı kabullenmek, empati kurmak, iş birliği ve karar hakkını desteklemek gibi) temel becerilerini terapi sürecine dahil edebilmeleri kastedilmektedir (Arkowitz ve Burke; Arkowitz ve Westra).

Her ne kadar çok sayıda depresyon psikoterapisi biçimi, davranış değişikliğini (örneğin davranış aktivasyonu, iletişim davranışları) farklı derecelerle önem vererek irdelemiş olsa da özellikle sağlık davranışlarını hedefleyen (Motivasyonel Görüsşme gibi) kanıta dayalı müdahalelerin birleştirilmesi depresyon tedavisinin etkinliğini ne kadar artıracağ 1 konusu yeteri kadar incelenmemiştir. Bunun yanı sıra, depresyonun Motivasyonel Görüşme yardımıyla nasıl irdelenebileceğini anlamaya yönelik çalışmalar henüz çok yetersiz düzeydedir (Arkowitz, Westra, Miller \& Rollnick, 2008). Bilişsel Davranışçı Terapi, depresyon tedavisi sürecinde Motivasyonel Görüşme'nin kullanışl1lı̆̆ını genişletmek için Motivasyonel Görüşme ile entegrasyonu mümkün kılabilen oldukça gelişmiş ve çalışılmış özel tedavi yöntemi sağlamaktadır. Ancak böylelikle her iki müdahale arasında tam bir sinerjinin olası olduğuna dikkati çekmektedir.

\section{Motivasyonel Görüşme (MG)}

Motivasyonel Görüşme, Miller ve Rollnick (2002) tarafından "hasta merkezli ve kararsızlı̆̆ bulup ortadan kaldırma itibarıyla içsel motivasyonu yükseltmek için yol gösterim metodu" olarak tanımlanmıştır. Tek başına psikoterapinin ayrı bir türü olmamasının haddi zatında Motivasyonel Görüşme, aslında insanların belirli bir davranışını değiştirmeye yardımcı olmak, diğer tedavi ve müdahale yaklaşımlarıyla uyum içerisinde kullanılmak için geliştirilmiş "insanlarla olmanın bir yolu" olarak algılanabilir. Motivasyonel Görüşmenin dört ana esas1, a) empati kurma, b) farkındalık uyandırma, c) direnci kabullenme, d) öz-etkinliği desteklemek olarak sıralanmıştır (Miller \& Rollnick, 2002). Son zamanlardaki araştırmalar gösteriyor ki eylemlerinin Motivasyonel Görüşme mekanizmaları, terapistin hem ilişkisel bileşen (empati ve İş Birliği, Evokasyon, Özerkliğe Saygı olarak tanımlanan "Motivasyonel Görüşme Ruhu”) hem de teknik bileşende (“değişim konuşması" olarak bilinen hastanın değişmek için isteğini dile getirmesini sağlamakta) becerikli olmasını gerektirmektedir [Moyers \& Martin, 2006] ve [Moyers vd., 2005] ).

Motivasyonel Görüşme kapsamlı bir biçimde araştırılmış ve tedaviye bağlılığ artırdığ1 ve daha sonraki tedavi yöntemlerinin etkinliğini yükseltmeye yararlı olduğu bulunmuştur (Burke, Arkowitz, \& Menchola, 2003). Madde istismarı ve diğer sağlık ve davranış sorunlarında hastanın tedaviye katılmasına müdahale bakımından Motivasyonel Görüşme'nin faydalarını konu edinen hatırı sayılır miktarda araştırma yapılmıştır (bkz. Burke vd., 2003; Noonan \& Moyers, 1997). Dikkat çekilmesi gereken bir nokta da Motivasyonel Görüşme'nin diğer tedavi yöntemlerine göre daha az zaman ve kaynak gerektirmesidir. Bu sayede Motivasyonel Görüşme'nin entegrasyona uygun ve aktarılabilir bir müdahale olarak belirli bir pratik faydası vardır. Aynı zamanda, Motivasyonel Görüşme 'nin madde kullanımı, AIDS riskli davranış, obezite, sigara bağımlılığı, gözaltı ve tahliye vak'aları, tedavi ve medikasyona riayet, beslenme davranışlarının da aralarında olduğu birçok sağlık-davranış alanlarında tek başına yeterli bir müdahale olduğu görülmüştür. Şimdiye kadar yapılan araştırmalara ve klinik gözlemlerine bakıldığında, Motivasyonel Görüşme 'nin özellikle ikilem yaşayan ve belirli bir davranış değişikliğine direnç gösteren bireylerde etkili ancak davranış değişikliğine istekli olan bireyler de ise; etkisiz olduğu görülmüştür. Son zamanlarda, klinisyen ve araştırmacılar, depresyon ve kaygı gibi psikiyatrik sorunların tedavisinde Motivasyonel Görüşme'nin uyarlanması ve entegrasyonuna ilgi göstermektedirler (Arkowitz vd., 2008).

\section{Bilișsel Davranışçı Terapi (BDT)}

Duygusal rahatsızlıkların bilişsel tasarısı ilk olarak 1960'lı yıllarda Aaron T. Beck tarafından ortaya atılmış ve bilişsel terapinin ortaya çıkmasına neden olmuştur (BT; Beck, Rush, \& Shaw, 1979). En öz ve temel şekliyle BT, bireyin kendisi, dünyası ve geleceğine dair olumsuz fikirlerini ve alakalı davranışlarını değiştirmeyi amaçlamıştır. BT, izleyen süreç içerisinde davranış̧̧ı teorik ve müdahale unsurlarının üzerinde durarak genişletildi ve günümüzde daha çok Bilişsel Davranışçı Terapi olarak bilinmektedir. 2000 tarihli bir makale tahlili Bilişsel Davranışçı Terapi’nin depresyonun da aralarında bulunduğu çeşitli rahatsızlıklar üzerinde yapılan 300'e yakın çalışmada tedavi sonuçlarını iyileştirmede etkili olduğunu göstermiştir (Butler \& Beck, 2000). Bilişsel Davranışçı Terapi’nin uygulamaları içerik bakımından oldukça farklılık gösterse de temel Bilişsel Davranış̧̧ı Terapi modeli, olaylar, fikirler, davranışlar ve ruh hali arasındaki etkileşime vurgu yapmaktadır. Bilişsel Davranışçı Terapi 'nin temel metotları, Wright, Basco \& Thase (2006), tarafından öğrenme kılavuzunda özetlenmiştir. Bu metotlar; sorun odaklı yaklaşım, bireysel vak'a kullanımı, 
işbirlikçi deneysellik, Sokratik sorgulama, yapılanma kullanımı, beceri psiko-eğitimi ve tekrarlanması, otomatik fikir ve şemaların oluşturulması ve düzenlenmesi, depresyona neden olan ve sürdüren davranışları azaltmak için davranışçı metotlar (davranış aktivasyonu) ve rahatsızlığın tekrarlanmaması için Bilişsel Davranışçı Terapi becerilerinin kullanılmasını içermektedir. Genel olarak, Bilişsel Davranış̧̧ı Terapi unipolar depresyon alanında en fazla araştırmanın yapıldı̆̆ 1 ve en sık başvurulan tedavilerden biridir.

\section{Motivasyonel Görüşme ve Bilişsel Davranış̧̧ı Terapi Arasındaki Önemli Benzerlik ve Farklııklar}

Açıkça belirtilmelidir ki; Motivasyonel Görüşme ve Bilişsel Davranışçı Terapi, günümüzdeki kullanım nitelikleriyle birbirlerinden tamamıyla ayrılmış değildir. Aksine, her iki yaklaşım da uzman kullanımın ayrılmaz parçası kabul edilen çok sayıda bileşen paylaşmaktadırlar. Hepsinden önemlisi, her ikisi de, hastalarla çalışırken işbirlikçi yaklaşıma önem vermektedir. Örnek vermek gerekirse, Bilişsel Davranış̧̧ı Terapi çalışmasında oturumun amaçları ve gündemi, hastalarla görüşülerek birlikte belirlenmektedir. Bilişsel Davranışçı Terapi uygulamaları terapötik hedeflere yönelik olarak hastalarla düzenli "iletişim kurmayı" gerektirmektedir. "İşbirlikçi deneyselcilik" adı verilen metoda göre Bilişsel Davranışçı Terapi; ruh hali, olaylar, fikirler ve davranış arasındaki bağlantılar hakkında hasta ile birlikte hipotezler oluşturmaya ve test etmeye önem vermektedir. Bunun yanı sıra hastalarla işbirliği, klinisyenlerin Motivasyonel Görüşme'ye bağl1lıklarının sınıflandırıldığı başlıca alanlardan biridir. Her iki yaklaşımın da, belirli sorun ve davranışlar üzerinde yoğunlaştıklarında daha etkili olduğu anlaşılmaktadır. Motivasyonel Görüşme'nin dört ana esasından biri olan öz-etkinliği desteklemek, Bilişsel Davranışçı Terapi 'nin de tasarılarının çoğunda önemle vurgulanmıştır (O'Leary \& Wilson, 1987).

Her ikisi de iş birliğine önem addetmiş de olsalar, aralarındaki önemli bir fark Bilişsel Davranışçı Terapi’nin değişikliği sağlayacak esas birim olarak terapisti gördüğü uzman modelini vurgulamasıdır. Motivasyonel Görüşme'de ise; değişikliği sağlayacak uzman ve esas birimin hasta olduğu açıç̧a görülmektedir. Aynı zamanda Motivasyonel Görüşme, sınıflandırmaların önemsiz olduğunu vurgulamaktadır ve buna binaen bir Motivasyonel Görüşme klinisyeni hastasının bilişsel durumunu "mantıksız" veya "çarpık" olarak nitelendirmez. Bilişsel Davranışçı Terapi 'nin tamamen işbirlikçi bir yaklaşımını açıklarken Miller (1988) şu yorumu yapmıştır: Bilişsel-Davranışçı Terapi'yi, hangi görüşlerin "mantıklı" hangilerinin "mantıksız" olduğunu belirten sabit, peşin hükümler yerine hastanın öz değerlerinden oluşan amaçlarına göre yönlendirmek daha uygun olacaktır. Dolayısıyla, iş birliğinin artırılması Motivasyonel Görüşme ve arasında Bilişsel Davranışçı Terapi olası sinerjinin diğer önemli bir örneğidir.

\section{Motivasyonel Görüşme ve Bilişsel Davranışçı Terapi’nin Entegrasyonunun Gerekçeleri}

Yaygın kullanımı bulunan ve etkinliği ispat edilmiş olan Bilişsel Davranışçı Terapi, Motivasyonel Görüşme ile entegrasyonunun göz önünde bulundurulması neden gerekli olsun? Arkowitz ve Burke (2008), tedaviyi genel bağlamda geliştirme açısından Bilişsel Davranışçı Terapi ile Motivasyonel Görüşme'nin entegrasyonunun neden haklı olduğu hususunda çok sayıda önemli gerekçe sıralamıştır. Öncelikle Bilişsel Davranışçı Terapi çok sayıda depresyonlu hastaya faydalı olmuş olsa da genel tedaviye yanıt ve remisyon oranları göz önünde bulundurulduğunda gelişmeye ihtiyaç duyulduğu görülmektedir. Dört psikoterapi çeşidi (kişiler arası psikoterapi [KAP], Bilişsel Davranış̧̧ Terapi ve psikodinamik Psikoterapi) ile ilaçla tedavi ve plasebonun karşılaştırılmasıyla yapılan meta analiz; Bilişsel Davranış̧̧ Terapi 'nin KAP ve antidepresan medikasyonlar ile kıyaslanabilecek şekilde \%50 (Hollon vd., 2002) civarında tedaviye yanıt oranına sahip olduğunu ortaya koymuştur. Bunların tümü psikodinamik terapi ve plaseboyu geride bırakmıştır. Elde edilen verilere bakıldığında kontrol durumlarına göre elde edilen kayda değer genel istatiksel gelişmeye rağmen Bilişsel Davranışçı Terapi tedavisi (veya herhangi bir tedavi) görmüş yadsınamayacak sayıla depresyon hastasında semptomlar devam etmektedir (APA, 2000). Tamamlanmamış semptom remisyonunun, rahatsızlığın tekrarlama riskini artırdığı ve hayatı boyunca depresyona karşı güçsüzlüğe neden olduğu görülmüştür (Kupfer, 1991). Kronik depresyonun dünyadaki en yaygın fonksiyonel yetersizliklerin arasında olduğu (Lancet Global Mental Health Group vd., 2007) dikkate alındığında; klinik araştırmacılarının, denemelerde çoğunlukla elde ettikleri \%50-60 remisyon oranında olan depresyon tedavisi sonuçlarını daha iyiye taşıyacak yöntemler arayışında olması hayati önem taşımaktadır. 
Ayrıca Arkowitz ve Burke (2008), Motivasyonel Görüşme'nin depresyon “semptomlarına uygun olduğunun" altını çizmişlerdir. Motivasyon eksikliği ve değişim konusundaki ikilem gibi depresyon semptomları ve özellikleri Motivasyonel Görüşme'nin özel odaklarıdır. Yakın zamandaki çalışmalar, Bilişsel Davranışçı Terapi 'ye yanıt vermeyen ağır depresyon hastalarının bilişsel odak veya antidepresan medikasyonuna göre davranış aktivasyonu ile daha fazla ilerleme sağladığını kanıtlamış ( [Coffman vd., 2007] ve [Dimidjian vd., 2006] ) ve belirli sağlik davranışı değişimine bağl1lığı geliştirmek için farklı stratejileri birleştirme konusunda umut verici bir rol oynamıştır (Arkowitz \& Burke, 2008). Önemli olan bir diğer nokta da, Motivasyonel Görüşme'nin diğer tedavi yöntemleri ile birlikte kullanılmak için oldukça kısa biçimde tasarlanması ve test edilmesidir. Davranış değişikliği ve işbirlikçi çalışmaya verilen ortak önemin yanı sıra hem Bilişsel Davranışçı Terapi hem de Motivasyonel Görüşme'nin, hasta fikir/görüşleri ve davranışlarını müdahale amacı olarak göstermesinden dolayı iki yaklaşımın birleştirilmesi mantıklı görünmektedir.

Taylor ve Asmundson (2004) tarafindan özetlendiği gibi, bireyler tedaviye muhtelif sebepler ve farkl1 motivasyon seviyeleri ile gelmektedir. Genel olarak Motivasyonel Görüşme, motivasyon sorununun ortaya çıtığg bütün durumlarda Bilişsel Davranış̧̧ı Terapi ile birleştirilebilir. Kaygı ve depresif rahatsızlıklar için Motivasyonel Görüşme ve Bilişsel Davranışçı Terapi 'nin entegrasyonunu açıklayan daha önceki bir makalelerinde Arkowitz ve Westra (2004), Bilişsel Davranışçı Terapi 'nin tedavi ve değişiklik konusunda yaşanan ikilemi irdelemediğinin; aksine hastalara belirli değişim ve becerilere yönelik yardım sağladığının altını çizmiştir. Bu bağlamda Motivasyonel Görüşme, değişim için motivasyonun kazanılması için belirli ve stratejik bir odak sağlamaktadır. Motivasyonel Görüşme, inisyal tedaviye katılım motivasyonunu artırmak (Zuckoff, Swartz \& Grote, 2008), tedaviyi hatırlama ve tedavinin (ödev davranış-aktivasyon teknikleri gibi) çeşitli yönlerine bağlılığı artırmak amacıyla birleştirilebilir. Bu sebeple temel Motivasyonel Görüşme becerileri, tedaviye bağlılığı ve sonuçları geliştirmek yoluyla Bilişsel Davranışçı Terapi ile sinerji oluşturabilir (Arkowitz \& Burke, 2008).

Entegrasyonunun gerekçelerinden bir diğeri de Motivasyonel Görüşme'nin birçok çalışmada elde edilen Bilişsel Davranışçı Terapi sonuçlarının önemli göstergelerini doğrudan ve stratejik olarak irdelemesidir (Arkowitz ve Burke, 2008). Motivasyonel Görüşme için temel bir beceri olan empati, tedavi çalışmalarında Bilişsel Davranışçı Terapi 'nin sonuçlarıyla ilişkilendirilmiştir ( [Burns \& Nolen-Hoeksema, 1991] , [Burns \& Nolen-Hoeksema, 1992] ve [Miller vd., 1980] ). 64 hasta üzerinde BT sürecini araştıran bir çalışmada (Castonguay, Goldfried, Wiser, Raue \& Hayes, 1996) hastanın odaklanma ve duygusal reaksiyonları kabul etme yeteneği olarak tanımlanan duygusal deneyimin depresyon sonuçlarını geliştirebileceği sonucuna varılmıştır. Diğer taraftan ise, çarpık düşünce ve olumsuz duygular arasında bağlantı kuran bir klinik odak, daha körü depresyon sonuçları öngörmektedir. Yapılan analizler gösteriyor ki; hislerinin yansıtılması ve kabul edilmesi ile davranış değişikliğini kolaylaştırmadan faydalanmak yerine terapistin Bilişsel Davranışçı Terapi modeline bağlı kalmada ısrar etmesi, özellikle de uyuşma sorunlarının bulunduğu durumlarda, daha kötü depresyon sonuçlarına neden olabilmektedir (Castonguay vd., 1996).

Bahsi geçen araştırma, yansıtıcı dinleme ve hastanın fikir motivasyonunu ortaya çıkarma gibi Motivasyonel Görüşme'nin temel becerilerinin entegrasyonunun Bilişsel Davranışçı Terapi sonuçlarını geliştirebileceği çıkarımında bulunmuştur. Terapist iletişim faktörleriyle alakalı olarak Motivasyonel Görüşme-Bilişsel Davranışçı Terapi entegrasyonunun diğer bir gerekçesi de klinik psikolojisi, psikiyatri asistanlığ 1 ve sosyal hizmet yüksek programları başta olmak üzere Bilişsel Davranışçı Terapi gibi kitaplaşmış terapilerle eğitim verilmesinin eleştiriye maruz kalmasıdır. Endişenin merkezinde belirli bir terapi modelinin "teknik" kısmının üzerinde aşırı durulması ve klinik sonuçlarını geliştirme olasılığı bulunan terapi şeklinin ve (daha önce belirtilen) becerilerin göz ardı edilmesi yatmaktadır. Bu nokta önemlidir. Çünkü, birçok çalışmada terapötik iletişim faktörlerinin psikoterapi sonucu üzerinde her hangi bir teknikle karşılaştırıldığında oldukça etkili olduğu gözlemlenmiştir (örneğin, [Beutler \& Clarkin, 1990] , [Burns \& Nolen-Hoeksema, 1992] ve [Lafferty vd., 1989] ). "Illişki duruşu” (Arkowitz ve Westra, 2004) ve "ilişki iyileştirme" (Arkowitz \& Burke, 2008) olarak bahsedilen Motivasyonel Görüşme ve Bilişsel Davranış̧̧ı Terapi eğitiminin entegrasyonu; empati, işbirliği, hasta fikirlerini uyarma, motivasyon, özerkliğe saygı (yani Motivasyonel Görüşme Ruhu) ve ikilemi irdeleme ve çözüme ulaştırma gibi terapist becerilerine dikkati çektiği için mantıklı bir yaklaşım olabilir (Arkowitz ve Burke). Bu esas Motivasyonel Görüşme becerileri, onaylanmış Motivasyonel Görüşme bağl1lık ve yeterlilik değerlendirme ölçeklerinden faydalanılarak incelenebilmekte ve öğretilebilmektedir (Moyers, Martin, Manuel, Hendrickson \& Miller, 2005). Klinik çalışmaları, terapistlere ait Motivasyonel Görüşme ruhu ve empati değerlerinin artmasının ancak Motivasyonel Görüşme denetimi ile mümkün olabileceğini ve psikoterapi eğitim modellerine yön gösterici olabileceğini göstermiştir (Miller, Yahne, Moyers, Martinez, \& Pirritano, 2004). 
Son olarak, Arkowitz ve Burke (2008), Bilişsel Davranışçı Terapi 'nin terapötik odağını belirlemek, belirginleştirmek ve sürdürmek amacıyla Motivasyonel Görüşme entegrasyonunun faydalarını ifade etmişlerdir. Hastanın değerleri ve hedefleri ile tutarlı bir şekilde yapılan "değişim konuşmasını” sağlamak, yansıtmak ve genişletmek sayesinde Motivasyonel Görüşme, bu odağın stratejik olarak sürdürülmesini sağlamaktadır. Arkowitz ve Burke (2008), Motivasyonel Görüşme'nin entegrasyonuyla stratejik yol gösterebilen ve sürdürülebilen çok sayıda odak konularını özetlemiştir. Bu konular; depresyonun genel sonuçlarının iyileştirilmesi, ruh hali bozukluklarına neden olan sorunların tespiti, depresyona sebep olan düşünce ve davranışların aktif değişimi ve antidepresan medikasyondan faydalanmadan ikilemi irdelemeyi içermektedir. Odak noktaları, işbirlikçi bir teknik benimseyerek hastanın değerlerinin düşünülmesi sonucunda genellikle bir "menü” şeklinde Motivasyonel Görüşme ile uyum içerisinde sunulmuştur. Hastanın belirli bir hedef (davranış aktivasyonu gibi) için hastadan motivasyon istemek ya da buyurmak yerine ortaya çıkarılmıştır ve bu odağın sürdürülmesi için hastadan izin talep edilmiştir.

\section{Bilişsel Davranışçı Terapi ve Motivasyonel Görüşme'nin Klinik Uygulamaları}

Hastanın ihtiyaçlarına terapötik bağlılık ve terapistin yanıt verebilirliği, davranış değişikliğinin başarılı bir şekilde gerçekleşmesine önemli ölçüde tesir etmektedir. Tedaviye katılım ve depresyon bazlı belirli davranış değişikliği, hasta ve terapist için zorlayıcı olabilmektedir. Zira ekseriyetle ikilem ve direnç ile karşı karşıya kalınmaktadır. Diğer taraftan depresyonun düzelmesi; tedaviye bağllık, takviye aktivitelerde artış ve bilhassa bilişsel ve iletişimsel değişmelerin de aralarında bulunduğu birçok davranış değişikliği hedefleri içerebilmektedir (Hollon vd., 2002). Bahsedilen iletişimsel etmenler ve tedavinin sonucunu etkileyen davranış değişikliği faktörleri, temel Motivasyonel Görüşme becerilerini oluşturmaktadır. Motivasyonel Görüşme-Bilişsel Davranış̧̧ı Terapi sinerjisinin bu kısımları tek tek aşağıda incelenmiştir. Bilişsel Davranış̧̧ı Terapi -Motivasyonel Görüşme entegrasyonunun özel alanları, klinik örnekler ile birlikte değerlendirilmiştir.

\section{Hasta-Terapist Etkileşimi Etmenleri}

Davranış değişikliği üzerinde çeşitli alanlarda gerçekleştirilmiş çalışmalar gösteriyor ki; müdahale stratejilerinin motivasyon ve öz-etkinlik gibi hastanın bireysel durumlarıyla uyum içerisinde olması gerekmektedir (DiClemente, 2007). Şu açıktır ki; başlangıçta tasarlandığı ve tedavi kitapçıklarında yaygın şekilde tanımlandığı şekliyle Bilişsel Davranışçı Terapi, psikoterapistlerin hastalarına özel tedaviler uygulamak için kliniksel kanaatleriyle birlikte uyum içinde kullandıkları bir sistemdir (Beck, 1995). Belirtildiği şekliyle işini iyi yapan Bilişsel Davranışçı Terapi terapistleri empati kurabilen, hastaların ihtiyaçlarını dikkate alan, işbirlikçi ve hastaların özerkliklerine sayg1lıdır ( [Burns \& Nolen-Hoeksema, 1991] ve [Miller vd., 1980]). Ancak, bazı Bilişsel Davranış̧ı Terapi terapistleri; tedaviyi başarı ile uygulamak için gerekli olan yeterli eğitim, denetim ve deneyime sahip olmayabilmektedir. Motivasyonel Görüşme, terapistlere hızlı çözüm oluşturmada yardımcı olabilecek ve Bilişsel Davranışçı Terapi ile entegrasyonu mümkün olan belirli bir metot sağlamaktadır (Arkowitz \& Burke, 2008).

Miller (2008), Motivasyonel Görüşme'nin psikoterapi ile entegrasyonu için kullanılabilecek dört genel yaklaşım ortaya koymuştur: a) insanın gelişim ve değişim potansiyeline inanç, b) iradenin asıl (seçim ve karar verme) rolüne vurgu, c) ikilemin anlayışla karşılanması ve kabul edilmesi, d) hasta ve klinisyen diline yakından ilgi. Dolayısıyla Motivasyonel Görüşme, psikoterapistlerin Bilişsel Davranışçı Terapi 'yi uygulama eğitimlerinde faydalanılabilecek stratejik olarak yanıt verebilen ve esnek, işbirlikçi ve empatik bir sistem ortaya koyabilmektedir. Empati, Motivasyonel Görüşme eğitimi ve denetlenmesinde açıkça vurgulanmıştır ve terapist empatisini artıracak şekilde denetleme mekanizmaları tasarlanmıştır (Arkowitz \& Burke, 2008). Empati, işbirliği, hastanın fikirlerini uyandırma ve hastanın özerkliğine saygının ilişkisel bileşenleriyle alakalı bu eğitim ve denetim yaklaşımlarının; Bilişsel Davranışçı Terapi ile stratejik olarak entegrasyonu sağlanabilir.

Depresyon psikoterapisi araştırmaları gösterdi ki; depresyon tedavisi sonuçlarındaki tutarsızlığın büyük bir kısmı; hastanın tedavi bağl1lığına katkısı (Krupnick vd., 1996), anlaşılma hissi, açık ve düzenli kendini ifade etmenin (Ablon \& Jones, 1999) de aralarında bulunduğu hasta faktörlerinden kaynaklanmaktadır (Beutler, Crago, \& Arizmendi, 1986). Bu ve farklı diğer araştırmalar birçok klinik vak'alarında ektili terapötik (Motivasyonel Görüşme gibi) yaklaşımlar, terapötik öğelerin uzman bilgisi dahilinde uygulanmasından ziyade hastalar tarafından 
sağlanmasının önemini vurgulamaktadır. Bu sıkça karşılaşılan durumun ve sonucunda ortaya çıkan psikoterapistler tedavi "eder" ifadesinin tam tersidir. Aksine uzman psikoterapistler; gerekli gördükleri bilgiyi, yöntemi, yönlendirmeyi aktarmak ile hastanın bireysel görüşlerini, becerilerini, kaynaklarını ve güçlü yönlerini kullanmasını sağlamak arasında mekik dokumaktadırlar. Bu itibarla gerek Bilişsel Davranışçı Terapi gerekse Motivasyonel Görüşme deneysel olarak entegrasyonu mümkün olan öğeler barındırmaktadır.

\section{İnisyal Tedaviye Katılım}

Depresyonlu olan kişiler özel bakım gerektirmediklerinden dolayı aile hekimliği ve diğer medikal ve sosyal ortamlarda belirlenmeli veya tedavi edilmeli ya da gönderilmelidir (Young, Klap, Sherbourne \& Wells, 2001). Bilişsel Davranışçı Terapi 'nin ihtisas dışı alanlarda ve duyarlı popülasyonlara uygulandığı çalışmalar tedaviye nispeten düşük bağl1lı olduğunu göstermiştir. Örneklemek gerekirse düşük gelirli kadınlar arasında yapılan araştırma ( [Appleby vd., 1997] , [Meager \& Milgrom, 1996] ve [Prendergast \& Austin, 2001] ), oturumlara katılımı teşvik eden yardımlara rağmen yüksek oranda (\%60'a yakın) tedaviden pişmanlık duyduklarını ortaya koymuştur.

Son yıllarda Motivasyonel Görüşme'nin tedavi için gerekli olan her şeyi harfiyen yerine getirmede ve diğer tedavi yöntemlerine bağl1lı̆̆ artırmada etkili olduğu bulunmuştur ve bu yüzden Bilişsel Davranışç1 Terapi 'ye katk1 sağlamayı vaat ettiği gözler önüne serilmiştir. Yakın tarihte yayınlanan bir makalelerinde Zuckoff ve diğerleri (2008), Motivasyonel Görüşme'yi depresyon tedavisi öncesi katılım seansında KAP'a bağl1lığı geliştirmek için umut vadeden bir yaklaşım olarak tanımlamışlardır. Yapılan çalışmalar, madde bağımlılı̆̆ı ve depresyonun yanı sıra kaygı rahatsızlıkları (Westra \& Dozois, 2006) ve kişilerarası şiddet (Musser, Semiatin, Taft \& Murphy, 2008) tedavilerinde de Motivasyonel Görüşme'den yararlanmışlardır.

Bu araştırmalar, tedaviye bağlılığın arttı̆̆ını ve vak'aların büyük bir bölümünde diğer tedavilere yanıt verme sonuçlarında gelişme sağlandığını göstermiş̧ir. Mesela, Westra ve Dozois, sosyal fobi veya kaygı bozukluğu olarak genelledikleri panik bozukluk yaşayan hastaların grup Bilişsel Davranışçı Terapi 'sinin öncesinde gerçekleştirdikleri üç Motivasyonel Görüşme oturumunun yalnızca grup Bilişsel Davranışçı Terapi 'sine göre oldukça yüksek kaygıda değişim, ödevlere uyum ve tedaviye tepki göstermeyi sağladığını bildirmişlerdir. Swartz ve diğerleri (2006), bir tek Motivasyonel Görüşme tedaviye katılım oturumunun KAP'ta yüksek oranda katılım (\%85) ve depresyon sorunu olan annelerde iyileştirilmiş depresyon ve çalışma sonuçlarına yol açtığını belirtmişlerdir. Yakın tarihli bir çalışmada kokain kullanımı rahatsızlığı olan 74 hasta rastgele ya Bilişsel Davranışçı Terapi ya da Bilişsel Davranışçı Terapi artı inisyal Motivasyonel Görüşme tedaviye katılım oturumu gruplarına ayrılmıştır. Motivasyonel Görüşme katılım oturumlarına devam eden hastalar, daha çok sayıda madde tedavisi oturumlarına katılmışlar ve kendilerine hakim ve tedavide başarılı olmayı daha çok arzulamışlardır (McKee vd., 2007).

$\mathrm{Bu}$ araştırmaların sonuçları, depresyonun Bilişsel Davranışçı Terapi tedavisinde Motivasyonel Görüşme'nin giriş kullanımı olarak gelişmeye devam edeceğine dair umut vaat ettiğini göstermektedir. Bu yöntem entegrasyon yerine kombinasyon olarak düşünülebilir ancak yine de Motivasyonel Görüşme ve Bilişsel Davranışçı Terapi için umut verici bir klinik çalı̧̧ması konusudur. Psikolojik Sorunların Tedavisinde Motivasyonel Görüşme isimli kitaplarının yakın tarihli baskısında Arkowitz ve diğerleri (2008), Motivasyonel Görüşme'nin kanıt temeli ve uygulamalarını kaygı bozukluğu ve duygusal düzensizlik için uzman tedavilerinde faydalanılabilecek etkili ve umut vadeden bir başlangıç olarak belirtmişlerdir. Aşağıdaki tedavi katılım örneği, belirli Bilişsel Davranışçı Terapi klinik etkileşimleriyle birleştirilebilen Motivasyonel Görüşme becerilerini göstermek amaciyla sunulan üç klinik örneğinden ilkidir.

Katılımcılık Örneği (Motivasyonel Görüşme becerileri italik olarak belirtilmiştir).

T: Anladığım kadarıyla aile hekiminin seni depresyon psikoterapisine yönlendirdi. Sen bu konuda ne hissediyorsun? (ikilemi açığa çıkarma; açık uçlu soru).

H: Aile hekimimin depresyon halimden nasıl kurtulabileceğimi düşündüğünden emin değilim. Kendimi yıllardır bu şekilde hissediyorum.

T: Burada olmanın sana yardım edebileceğinden emin değilsin yani (direnci kabullenme; hisleri yansıtma). 
H: Evet, kendi kendime birkaç şey denedim ki bunlar biraz yardımcı oluyor ama birisiyle konuşmanın durumumu nasıl değiştirebileceğini bilmiyorum.

$\mathrm{T}$ : Bu durumu düzeltmek için çaba göstermek istiyorsun (değişim konuşmasını ifade etmek). Ne çeşit şeyler sana biraz da olsa yardımcı olabiliyor? (daha fazla değişim konuşması ortaya çıkarma, açık uçlu soru)

H: Şey, kendimi köpeği yürüyüşe çıkarmaya zorladığımda biraz daha iyi hissediyorum. Ayrıca, arkadaşlarım dışarı davet ettiklerinde, biraz keyif alabiliyorum fakat bu tarz davranışları sık yapabilecek enerjim gerçekten yok.

T: Fiziksel ve sosyal olarak aktif olmanın ruh haline yardım ediyor olması oldukça mantıklı ve depresyonunun bu şeyleri yapmanda bir engel oluşturması da anlaşılabilir bir durum. Terapinin buna nasıl faydası olabileceği konusundan biraz bahsetsem senin için uygun olur mu? (ikilemi yansıtma, izin alma)

H: Tabii ki.

T: İnsanların özellikle kendilerini daha iyi hissettikleri davranışları daha fazla tekrarlamalarına yardım eden ve senin zaten fark edip üzerinde durmaya başladığın düşünme, aktivite, enerji ve ruh hali arasında bir bağlantı kuran bir tür terapi vardır (hastanın değişim hakkındaki kendi görüşleriyle ilintili olan Bilişsel Davranışçı Terapi yönleri hakkında psikoeğitimi ile ilgili yansıtma özeti). Bu senin için uygun mudur? (tedaviye katılım ile ilgili hem değişim konuşması hem de ikilem ortaya çıkarma)

H: İnsanlarla daha fazla şeyler yapabilmek için daha fazla enerjimin olmasını isterdim, bu yüzden mantıklı geliyor ama hala bu konuda konuşmanın yardımcı olacağından emin değilim.

T: Terapi sürecinde bu şeylere odaklanmanın yardımcı olup olamayacağı konusunda hala biraz kafan karışı ve aynı zamanda daha iyi olmak için elinden geleni yapmak istiyorsun (ikilemi kabullenmek, ikilemi yansıtmak). $\mathrm{Ne}$ yapmak istiyorsun? (değişim konuşmasını sağlama; özerkliğe saygı).

H: Sanırım denemenin bir mahsuru yok. Bu şekilde hissetmekten sıkıldım.

\section{Davranış Aktivasyonu}

Davranış aktivasyonu Bilişsel Davranış̧̧ı Terapi'nin temel yapıtaşıdır ve özellikle daha şiddetli depresyon vak'alarında temel bir etki mekanizması olarak gitgide büyüyen bir araştırma desteği almaktadır ( [Coffman vd., 2007] ve [MG Dimidjian vd., 2006] ). Daha önce bahsedildiği gibi, Motivasyonel Görüşme en iyi davranış değişikliği hedefleyerek çalışır ve özellikle bunun için geliştirtmiştir. Aktivite zamanlama, egzersiz, artan ya da ters yönde değişen kişiler arası davranışlar ve davranıştan kaçınma ve derin düşünmenin azalması gibi davranış aktivasyonunu hedefleyen bazı belirli davranışlar bulunmaktadır. Bu her bir davranış değişikliği hedefi hastanın ikilem ve kaçınması ile karşılanabilir.

Motivasyonel Görüşme terapistleri direnç/ikilem fark etme, direnci "kabullenme" (örneğin; tartısmadan kaçınma), ve değişim yönünde hasta konuşmasını sağlamak ve arttırmak (değişim konuşması) konularında özellikle ve stratejik olarak eğitilmişlerdir. Hasta değişim konuşması, özellikle bir hastanın kendini değişime adamasını ve davranış değişikliği için motivasyonunu dile getirdiği hasta dili olarak kullanılabilir. Değişim konuşması, özellikle davranış değişim sonuçlarını değiştirmede etkili olan dilbilim kodlamanın kullanıldığı çalışmalarda bulunmaktadır. Karşı değişim konuşması olarak da bilinen hastanın mevcut durumunu savunması, davranış değişikliği ile ters ilişkilidir (Moyers \& Martin, 2006; Moyers vd, 2005).

Davranış aktivasyon ödevlerinin tamamlanmasıyla ilgili olan hasta ikilemi, direncin terapist tarafindan tespit edildiği noktada Motivasyonel Görüşme'nin entegre edilmesiyle direk olarak irdelenebilir. İyi eğitimli Motivasyonel Görüşme terapistleri aynı zamanda ikilemi irdeleyerek ve direnci kabullenerek belli bir davranış değişim konuşmasını cesaretlendirme ve ortaya çıkarmak için birçok teknik kullanma konusunda yeteneklidirler. Bu yüzden, Bilişsel Davranış̧̧ı Terapi terapistlerinin genel klinik bilgilerine ve eğitimine Motivasyonel Görüşme eklenmesinin belirli depresyon hastalarına davranış değişikliği konusunda yardımcı olma becerilerini geliştirip geliştiremeyeceğinin araştırılması önemlidir.

Aşağıdaki klinik örnek, belirli bir hedef davranış (kişiler arası aktivasyon) değişikliğinin ikileminin fark edilmesi üzerine terapistin ikilemi anlamak ve çözüme kavuşturmak için Motivasyonel Görüşme tekniğini nasıl 
birleştirdiğini ve kötüleşen (kaçınma) ruh halini iyileştirmek için Bilişsel Davranışçı Terapi çalışmalarının ortak katkısını göstermektedir.

\section{Davranış Aktivasyon Örneği}

T: (Ruh hali ve davranış günlüğüne birlikte bakarak) Bu hafta ruh halin nasıldı? (açık uçlu soru).

H: Geri dönüp bu haftaya baktığımda, bu hafta sonu moralim oldukça bozuktu. Pazara gelindiğinde, kendimi zavallı hissediyordum ve kaçmanın yollarını düşünüyordum. Gördüğunnüz gibi, Cuma işten sonra daha fazla depresif hissetmeye başladım ama o noktada çok kötü değildi. Akşam yemeği için arkadaşlarımla buluşmak istemedim ve evde yalnız kaldım. Buradan sonra ruh halim daha da kötüye gitti.

T: Arkadaşlarınla gitseydin kendini nasıl hissedecektin? (öneri aktarmak yerine ruh hali hakkında konuşmaya davet etme; açık uçlu soru)

H: Muhtemelen biraz daha iyi ama eminim ki onlar benimle uğraşmaktan sıkıldılar ve ben böyle hissettiğimde dışarı çıkmak istemiyorum.

$\mathrm{T}$ : İstemesen de dışarı çıkmak ruh haline iyi gelebilirdi ve biraz keyifsiz hissetmenin arkadaşlarını rahatsız edebileceğinden endişelisin (ikilemi düşünerek direnci kabullenme).

H: Şey, böyle bir şey söylemediler ama ben doğru olduğu sanıyorum. Bu durumda da yalnız olmayı tercih ederim.

T: Herhangi bir şey söylememelerine rağmen, yalnız olmak sana arkadaşlarını rahatsız etmekten daha iyi gözüküyor. Arkadaşlarının senden bıkmış olduğu şüphen bazen kendini iyi hissetmene yardımc1 olabilecek bir davranışı yapmanı engelliyor (yansıtma: direnci kabullenme). Bu durumlarda ruh halini dışarı çıkarak biraz arttırmak, 10 çok önemli olmak üzere, 0 ile 10 arasında ne kadar önemli?

H: Sanırım 8.

T: Peki neden 0 değil de 8? (değişim konuşması sağlama).

H: Bu günlüğün kullanımıyla fark ettim ki; eğer kendimi üzgün hissettiğimde onunla alakalı bir şey yaparsam biraz yardımcı oluyor. Sonra bir şeyler yapabilmek için biraz daha fazla enerjim varmış gibi geliyor. Bütün hafta sonlarımı bu şeklide kaybetmeye devam edemem. Çocuklarla tek zamanım hafta sonlarım.

T: Kendin ve çocukların için kendini iyi hissetmen senin için çok önemli (onaylama; değişim konuşmasını yansıtmak). Diğerleri üzerindeki etkisini de düşünerek, kendini üzgün hissettiğin bir sonraki durumda sana neyin yardımcı olabileceğini düşünüyorsun? (hasta stratejilerini ortaya çıkarma).

H: Sanırım, her halükarda kendimi dışarı çıkmaya zorlayacağım ve dışarı çıktığımda en azından arkadaşlarımla iletişime girmeye çalışacağım. En nihayetinde bu iyi bir kafa dağıtma şekli.

$\mathrm{T}$ : $\mathrm{Bu}$ bana mantıklı geliyor. Bu zor işe kendini adamayı devam ettirmek senin için çok önemli olmalı (onaylama; davranış değişimi planını yansıtma).

$\mathrm{Bu}$ örnek Bilişsel Davranışçı Terapi ve Motivasyonel Görüşme arasındaki sinerjiyi temsil etmektedir. Görüldüğü üzere, davranışsal kaçınma ve aktivasyon üzerindeki odak Bilişsel Davranışçı Terapi ile tutarlıdır. İkilemin irdelemesi, direncin kabullenilmesi, motivasyonun artırılması ve belirli bir davranış hakkında hasta değişim konuşmasını sağlamak Motivasyonel Görüşme ile tutarlıdır. Bu hem Bilişsel Davranışçı Terapi hem de Motivasyonel Görüşme eğitimi almış bir terapistin Motivasyonel Görüşme'yi terapinin mantıklı noktalarına nasıl entegre edebildiğinin bir örneğidir ( örneğin, belirli davranış değiş̧ikliği direnci ile karşılaşıldığında)

\section{Ödeve Riayet}

Literatürde bazı tutarsızlıklar olmasına rağmen, Bilişsel Davranış̧̧ı Terapi’ de ödeve riayetin sonuç üzerinde önemli bir araç olduğu konusunda göz ardı edilemeyecek miktarda kanıt bulunmaktadır ( [Burns \& Nolen-Hoeksema, 1991] , [Burns \& Spangler, 2000] , [Detweiler \& Whisman, 1999] ve [Rees vd., 2005] ). Motivasyonel Görüşme'nin temel prensiplerinden biri, kliniğin önerisi üzerine tedavinin yerine getirilmemesinden etkilenen ikilemin normal olmasıdır. Motivasyonel Görüşme, direnç ve ikilemi irdeleyen belirli teknik ve stratejiler sağlamaktadır. Bu özelliğiyle Motivasyonel Görüşme, Bilişsel Davranışçı Terapi klinisyenleri için ödev tamamlama ile ilgili ortaya çıkan zorlukları aşmak için kullanabilecekleri açık ve belirli bir sistem sağlamaktadır. Motivasyonel Görüşme eğitimi almış Bilişsel Davranışçı Terapi terapisti, ödev tamamlama eksikliğini kararsızlı̆̆ın incelenmesi ve yansıtılması ile ortaya 
çıkabilecek ikilemin (direnç) bir göstergesi olarak kullanabilir. Motivasyonel Görüşme'nin ikilemi inceleme ve Bilişsel Davranışçı Terapi ödevine ilişkin hasta değişim konuşmasını sağlama becerileri aşağıda sunulmuştur.

\section{Ödev Örneği}

T: Geçen hafta tartıştığımız düşünce-ruh hali kağıdına bakabiliriz ya da bugün senin istediğin bir konu ile de başlayabiliriz. Senin için hangisi en faydalı olurdu? (gündem konusunda ortak karar alma).

H: Dürüst olmak gerekirse, düşünce-ruh hali kağıdına bakamadım. Çok meşguldüm.

$\mathrm{T}$ : Bu hafta oldukça fazla yapacakların vardı (direnci kabullenmeyi yansıtmak). Bunun üzerinde çalışmak senin için nasıl bir şey? (ikilemi ortaya çıkarma; açık uçlu soru).

$\mathrm{H}$ : Bilemiyorum, ne kadar faydalı olacağı konusunda emin değilim ve sen bana düşüncelerimi değiştirebileceğimi söylüyorsun ve bu bana imkansız gibi geliyor.

T: Düşünmeni değiştirmek şu anda başarabileceğimizin ötesinde görünüyor olabilir ve zamanını sana faydalı olduğundan emin olduğun şeyler ile geçirmek istiyorsun (direnci kabullenme; yansıtma). Kendini en iyi sen tanıyabilirsin. Senin bakış açına göre, senin ruh halini düzeltmek için yapabileceğin ne var? (hedefler üzerinde iş birliği, hasta özerkliğine vurgu yapma).

H: Şey, biraz daha iyi hissettiğimde neler düşündüğüm ve yaptıklarıma dikkat etmek yardımcı oldu fakat verdiğiniz kağıt biraz kafa karıştırıcı. Bunu bilgisayarıma farklı bir şekilde not etmeyi tercih ederdim. T: Senin için ruh halini en kolay ve anlamlı şekilde (düşünme, özerkliği destekleme) takip edebilmek çok faydalı olacaktır. Ne yaparsan senin için faydalı olabileceğini düşünüyorsun? (saygı duyma, özerklik, strateji çıkarımı)

\section{Sonuç ve Öneriler}

Bilişsel Davranış̧̧ı Terapi 'nin depresyonun tekrarlamasını engellemenin yanı sıra rahatsızlı̆̆ın tedavisindeki etkililiği üzerine yapılan klinik çalışmalar, Bilişsel Davranışçı Terapi 'nin depresyon tedavisinde tutarlı klinik sonuçları veren ve en yaygın olarak kullanılan kanıta dayalı tedavilerden biri olduğunu ortaya koymuştur. Depresyonun önemli bozukluklara neden olduğu saptanmıştır ve depresyonun tamamlanmamış remisyon karşısında tekrarlama riski yaygın ve belirgindir. Bu yüzden, mevcut depresyon tedavisi yöntemlerini geliştirmek için stratejiler araştırmaya devam etmek kritik önem taşımaktadır. Motivasyonel Görüşme, algılamayı ve diğer uzman tedavilerin sonuçlarını ve belirli davranış değişikliği sonuçlarını geliştiren kanıta dayalı bir stratejidir ve empati ve iş birliği gibi kanıta dayalı klinik etkileşim faktörleri üzerinde durmaktadır. Bu hasta merkezli faktörlerin depresyon psikoterapisi sonuçlarına katkıları olduğu bilinmektedir.

Motivasyonel Görüşme ve Bilişsel Davranışçı Terapi birleşiminin depresyon sonuçlarını geliştirip geliştirememesine karar verebilmek için yeni araştırmaların yapılmasına ihtiyaç vardır. Öncelikle, çalışmalar Bilişsel Davranış̧̧ Terapi 'nin öğrenme, katılım, uyum ve sonuçlar (örneğin, arttırıcı bir etki) üzerinde Bilişsel Davranışçı Terapi öncesindeki Motivasyonel Görüşme'nin etkisini İnceleyebilir. Ayrıca, Motivasyonel Görüşme’nin Bilişsel Davranışçı Terapi üzerinde sinerjik etkisi; depresyon hastalarının Motivasyonel Görüşme eğitimi almamış (örneğin, terapistler Motivasyonel Görüşme bağl1lığını ve yeterliliğini düşük olarak değerlendiren) terapistler tarafindan uygulanan Bilişsel Davranışçı Terapi grubuna ya da Motivasyonel Görüşme bağlılığını ve yeterliliğini yüksek olarak değerlendiren terapistlerin olduğu Bilişsel Davranışçı Terapi grubuna atanarak rastgele ve kontrollü denemelerle araştırılabilir. Temel sonuçlar; tedaviye bağl1lık, depresyon ve çalışma sonuçlarını içerebilir. Bu çalışmadan beklenen, sonuçların yönlendirici ve uzlaştırıcılarını tespit etmesidir. Örneğin, yönlendirici ihtiyacı/terciği düşük ya da yüksek olan hastalar, Motivasyonel Görüşme entegrasyonu olsun olmasın Bilişsel Davranışçı Terapi'ye farklı sonuçlar gösterebilirler. Bilişsel Davranışçı Terapi bazlı yaklaşımlarla karşılaştırıldığında genel olarak yüksek direnç gösteren hastaların Motivasyonel Görüşme’ye daha iyi tepki verdiklerine dair literatürde göstergeler bulunmaktadır. Hakkında araştırma yapılması gereken uzlaştırıcılar, belirli depresyon semptom kümeleri ve depresyon şiddetini içermektedir. Örneğin, özellikle kişiler arası bir (Motivasyonel Görüşme ile tutarlı) duruş sağlamanın; orta ve şiddetli nörovejetatif semptomları bilinmeyen bir birey ile teröpatik sonuçları ne kadar geliştireceği bilinmemektedir.

Genel olarak şu açıkça anlaşılmıştır ki depresyonu atlatma; tedaviye bağllık, egzersiz gibi güçlendirici aktiviteler ve bilişsel, kişilerarası değişikliğin de aralarında bulunduğu birçok davranış değiş̧ikliği içermektedir 
İlgar \& Coşgun-İlgar

(Hollon vd., 2002). Motivasyonel Görüşme sağlık davranışı değiştirme çalışmalarında en ön sırada yer almaktadır. Motivasyonel Görüşme gibi belirli ve gelişmiş bir davranış değişikliği müdahale yöntemi ile Bilişsel Davranışçı Terapi gibi depresyon için mevcut bir psikoterapi yönteminin birleştirilmesinin depresyon tedavisinin genel etkililiğini ne kadar geliştireceği araştırma konusu olmayı hak etmektedir. 


\section{Extended Summary}

The concept of behavior can be defined as reactions of living organisms that can be observed from the outside and can be determined based on the results. When we analyze human behaviors, we can see that motives, emotions, personal characteristics, genetic capacity, developmental process and experiences have impact on the formation of behaviors. Extrinsic stimulants interact with intrinsic stimulants, and then they undergo a series of processes in cognitive field and finally form reactions. One single stimulant can cause more than one reaction, or one single reaction can be formed on the basis of more than one stimulant.

Baymur (1994) states that, in order to be able to figure out how an individual will react to a stimulant, one must have information about these factors: a. Biological Features: The developmental period of individual, intelligence level, gender and interests. b. Past Life experiences: Settlements, educational history, experiences, knowledge and habits of individual. c. Present Intrinsic State: Psychological state of individual, the state of being hungry or not, feeling rested or tired, being willing or not. d. Environmental Conditions: Season, temperature, light, sound, loneliness, being in a group.

Cognitive Behavioral Change is a method of intervention involving both cognitive and behavioral learning principals. In fact, Cognitive Behavioral Change represents theoretical and practical assumptions involving these three assumptions:

a) Behaviors of individual are determined by cognitive phenomenon,

b) A change in cognitive phenomenon causes change in behavior,

c) Individual is an active participator in personal learning process. Shortly, Cognitive Behavioral approach accepts that personal capacity and preferences are efficient in controlling and managing personal behaviors (Heflin and Simpson, 1998).

Cognitive Behavioral Change method aims at teaching individual follow and control personal behaviors, attitudes and performances and properly carry out internal reinforcement. In this context, Cognitive Behavioral Change emphasizes the significance of changing thoughts in order to change feelings and behaviors (Corey, 1991; Harris, 1988).

Cognitive Behavioral Change is a technique involving both cognitive and behavioral dimensions. The technique is established in order to be able to increase self-control. An individual who has the ability of self-control is expected to follow and control his personal behavior and performance and reinforce expected behavior. Studies in the related literature show that various Cognitive Behavioral Change methods have been efficient in the studies with individuals with disabilities. The method also gives hope for the studies with autistic individuals.

The first stage of therapy starts with psycho-education and the goal is to enable the child to realize emotional/physical indications of anxiety. In the second stage, the aim is to determine thoughts, beliefs and self-talk that creates anxiety. In the third stage the child starts using the abilities of changing self-talk and problem solving through relaxation and cognitive reconstruction; the child realizes that nonfunctional thinking styles can be eliminated and it is possible to cope with anxiety caused by negative thoughts through abilities he has. In the final stage, exposure technique is used, and the child progressively faces with situation/phenomenon that causes fear. In this process, the child uses the abilities he learnt until that point, the results of coping skills are evaluated at the end of the process and he rewards himself (Kendall and Hedtke, 2006a; Kendall and Hedtke, 2006b).

Cognitive behavioral change is used in solving various problems such as aggression, anxiety, drug abuse, schizophrenia, bipolar disorder, borderline personality disorder, depression, social problem solving problems and limited auto control (Kendall, 1993; Larson and Lochman, 2002; Leahy and Beck, 1988; Mayer, Lochman, and Acker, 2005). This technique is also successful in individuals with autism (Quinn, Swaggart, and Myles, 1994). It is used in the education of children with special requirements.

The fields in which Cognitive behavioral change is used are presented below:

(a) Private Education: Individuals with autism, Asberger syndrome, Attention Deficit Hyperactivity Disorder" (ADHD), individuals with low level mental deficiency, children who are nonadaptive (Kendall, 1993; Larson and Lochman, 2002; Leahy and Beck, 1988; Lochman and Acker, 2005; Quinn, Swaggart and Myles, 1994). 
(b) Psychological Counseling and Psychotherapy: According to cognitive therapy, depression, anxiety and anger results from the recurrent patterns of cognitive distortions.

Cognitive distortions (negative beliefs): Reading mind, making predictions about future, catastrophic cognitions, labeling, ignoring positive processes, negative selectivity, over-generalization, dichotomous thinking, impositions, accusation, inequitable comparisons, tendency to sorrow, what if, emotional inference, non-falsification, focusing on judgment (Leahy, transl.: Vardareli and Türkçapar,2010).

Cognitive Behavioral Therapy presents professional assistance to individuals in order to enable them to overcome such negative thoughts. The most common therapies used for overcoming negative beliefs are: Rational Emotive Therapy, New Reality Therapy, Social Cognitive Theory and Cognitive Therapy. Besides these fields, cognitive therapies are used for coping with various problems including generalized anxiety disorder, hypochondria, post-traumatic stress disorder, marriage conflicts, sexual dysfunctions, borderline personality disorder, psychotic disorder, physical disability (Leahyçev: Hacak, Macit and Özpilavc1,2007)

In the last section of this study, an application example of the use of Motivational Interview Approach and Cognitive Behavioral Therapy Integration as a behavioral change technique in depression treatment is presented to the readers. 


\section{Kaynakça / References}

Ata, E. E. (2014). Kısa bilişsel davranışçı stres yönetimi programının şizofreni hastalarının bakım vericilerinin, ruhsal durumları, stresle başaçıkma tutumları ve bakım yüküne etkisi (Yayınlanmamış Doktora Tezi). Cumhuriyet Üniversitesi, Sağl1k Bilimleri Enstitüsü, Sivas.

Avcı, E. (2017). Madde bağımlılı̆̆ı tedavisi görmüş bireylerde bilişsel davranış̧̧ı grup psikoterapisinin relaps eğilimi üzerindeki etkisinin sınanması (Yayınlanmamış Doktora Tezi). İstanbul Arel Üniversitesi, Sosyal Bilimler Enstitüsü, İstanbul.

Ay, E. (2018). Kanserli çocuğu olan ebeveynlere verilen bilişsel davranış̧̧ı yaklaşım temelli psiko-eğitimin umutsuzluk ve stresle baş etme üzerine etkisinin incelenmesi (Yayınlanmamış Doktora Tezi). Atatürk Üniversitesi, Sağlık Bilimleri Enstitüsü, Erzurum.

Balcı, H. (2014). Bilişsel Davranış̧̧ Terapi ile tedavi edilen vajinismuslu kadınlarda ve eşlerinde tedavi öncesi ve sonrası benlik saygısı, öz-yeterlilik ve yaşam kalitesi düzeyleri (Yayınlanmamış Tıpta Uzmanlık Tezi). Marmara Üniversitesi, Tıp Fakültesi, Psikiyatri Anabilim Dalı, İstanbul.

Barry, L. M., \& Singer, G.H.S. (2001). A family in crisis: Replacing the aggressive behavior of a child with autism toward an infant sibling. Journal of Positive Behavior Interventions, 3(28-38).

Baymur, F. (1994). Genel psikoloji. İstanbul: İnkılap ve Aka Yayınevi.

Ben-Arieh, J., \& Myles, B. S. (2003). The use of a cognitive behavior modification strategy to increase on-task behavior in a student with Asperger Syndrome. Journal of the International Association of Special Education, 4, ss. 19-28.

Buğa, A. (2015). Bilişsel davranış̧̧ yaklaşıma dayalı web tabanlı interaktif ve geleneksel psiko-eğitim programlarının çocukların bilişsel hatalarına ve psikolojik belirtilerine etkisi (Yayınlanmamış Doktora Tezi). Gaziantep Üniversitesi, Eğitim Bilimleri Enstitüsü, Gaziantep.

Callahan, K., \& Rademacher, J. A. (1999). Using self-management strategies to increase the on-task behavior of a student with autism. Journal of Positive Behavior Interventions, 1, 117-122.

Corey, F. (1991). Theory and practice of counseling and psychotherapy. Belmont, CA: Books/Cole Publishing Company.

Elmacı, F. (2008). Bilişsel - davranışçı yaklaşıma dayalı grupla psikolojik danışmanın ergenlerin korkuları üzerindeki etkisi (Yayınlanmamış Doktora Tezi ). Ankara Üniversitesi, Eğitim Bilimleri Enstitüsü, Ankara.

Ersanl1, E. (2007). Evlilik ilişkilerinde eşlerin akılcı olmayan inançlarıyla başetmelerine bilişsel-davranış̧̧ı yaklaşıma dayalı evlilik iliş̧kisini geliştirme programının etkisi (Yayınlanmamış Doktora Tezi). Ondokuz Mayıs Üniversitesi, Sosyal Bilimler Enstitüsü, Samsun.

Flynn, H. A. (2011). Setting The Stage For The Integration Of Motivational Intervewing With Cognitive Behavioral Therapy In The Treatment Of Depression. (Unpublished Doctoral Thesis) Cognitive And Behavioral Pratice. Michigan Üniversity, 18.

Gökkaya, F. (2015). İlköğretim öğrencilerinde zorbalı eğilimini azaltmaya yönelik bilişsel davranış̧̧ı bir müdahale programının gelişstirilmesi ve etkililiğinin değerlendirilmesi (Yayınlanmamış Doktora Tezi). Ege Üniversitesi, Sosyal Bilimler Enstitüsü, İzmir.

Harris, K. R. (1988). Cognitive-behavior modification: Application with exceptional students. In E. L. Meyen, G. A. Vergason \& R. J. Whelan (Eds.), Effective instructional strategies for exceptional children. Denver, CO: Love Publishing Company, 253-268. 
İlgar \& Coşgun-İlgar

Heflin, L. J., \& Simpson, R. L. (1998). Interventions for children and youth with autism: Prudent choices in a world of exaggerated claims and empty promises. Part I: Intervention and treatment option review. Focus on Autism and Other Developmental Disabilities, 13, 194-211.

Hiçdurmaz, D. (2010). Bilişsel-davranışçı grup danışmanlığının benlik algısı ve stresle baş etme biçimlerine etkisi (Yayınlanmamış Doktora Tezi). Hacettepe Üniversitesi, Sağlık Bilimleri Enstitüsü, Ankara.

Kaplan, J. S., \& Carter, J. (1995). Beyond behavior modification: A cognitive-behavioral management in the school (3rd ed.). Austin, TX: Pro-Ed.

approach to behavior

Karahan F.T. \& Sardoğan E. M. (2004). Psikolojik danışma ve psikoterapide kuramlar. Samsun: Deniz kültür Yayınları.

Kendall, P. C. (1993). Cognitive-behavioral therapies with youth: Guiding theory, current status, and emerging developments. Journal of Consulting and Clinical Psychology, 61, 235-247.

Koegel, R. L., Hurley, C., \& Frea, W. D. (1992). Improving social skills and disruptive behavior in children with autism through self-management. Journal of Applied Behavior Analysis, 25, 341-353.

Koegel, R. L., \& Koegel, L. K. (1990). Extended reductions in stereotypic behavior of students with autism through a self-management treatment package. Journal of Applied Behavior Analysis, 23, 119-127.

Kurtoğlu, G. (2013). Bilişsel davranışçı yaklaşıma dayalı psiko-eğitim programının ilköğretim birinci kademe ögrencilerinin duygusal yllmazlık, sosyal beceri - okula uyum ve benlik sayglsı düzeylerine etkisi (Yayınlanmamış Doktora Tezi).Ege Üniversitesi, Sosyal Bilimler Enstitüsü, İzmir

Leahy, R. L., \& Beck, A. T. (1988). Cognitive therapy of depression and mania. In A. Gorgotas ve R. Cancro (Eds.), Depression and mania. New York: Elsevier, 214-267.

Leahy, R. L. (2007). Bilişsel terapi ve uygulamalart. Tedavi müdaheleleri için bir klavuz. Çev: H. Hacak, M. Macit, F. Özpilavcı. Ed. T. Özakkaş, İstanbul: Litera Yayıncılık.

Leahy.R.L. (2010). Bilişsel terapi yöntemleri Çev:K.Vardareli ve H.Türkçapar. İstanbul: Hekimler Yayın Birliği.

Mayer, M., Lochman, J., \& Acker, R. V. (2005). Introduction to the special issue: Cognitive-behavior interventions with students with EBD. Behavioral Disorders, 30, 197-212.

Meichenbaum, D. (1980). Cognitive-behavior modification: A promise yet unfulfilled. Exceptional Education Quarterly, 1, 83-88.

Quinn, C., Swaggart, B. L., \& Myles, B. S. (1994). Implementing cognitive behavior management programs for persons with autism. Focus on Autistic Behavior, 9(4), ss. 1-13.

Özdel, K. (2009). Bilişsel Davranış̧̧ı Terapi ile tedavi edilen vajinismus olgularında tedavi öncesi ve sonrası depresyon, anksiyete ve mükemmeliyetçilik düzeyleri (Yayınlanmamış Tıpta Uzmanlık Tezi). Ankara Üniveritesi Tıp Fakültesi, Ankara.

Özü, Ö. (2010). Bilişsel davranışçı yaklaşıma dayalı stresle başa çıma becerileri eğitim programının işgörenlerin stres, kaygı ve iyilik hali düzeylerine etkisi: Karşıyaka vergi dairesi örneği (Yayınlanmamış Doktora Tezi). Ege Üniversitesi, Sosyal Bilimler Enstitüsü, İzmir.

Palmen, A., Didden, R., \& Arts, M. (2008). Improving question asking in high-functioning adolescents with autism spectrum disorders. Autism, 12, 83-98.

Pehlivan, H. (2011). Bilişsel davranış̧̧ı yaklaşım temelli psikoeğitim programının kadın danışma merkezine başvuran annelerin iyi oluş düzeyi, evlilik doyumu, problem çözme ve iletişim becerilerine etkisi (Yayınlanmamış Doktora Tezi). Ege Üniversitesi, Sosyal Bilimler Enstitüsü, İzmir. 
Sapmaz, F. (2011). Bilişsel davranışçı yaklaşıma dayalı grupla psikolojik danışmanın sosyal anksiyete, reddedilme duyarlılı̆̆ ve kişilerarası duyarlılık üzerine etkisi (Yayınlanmamış Doktora Tezi). Sakarya Üniversitesi, Eğitim Bilimleri Enstitüsü, Sakarya.

Sarısoy, M. (2011). Bilişsel davranışç yaklaşıma dayalı grupla psikolojik danışmanın üniversite öğrencilerinin ruhsal belirti düzeylerine etkisi (Yayınlanmamış Doktora Tezi). Ege Üniversitesi, Sosyal Bilimler Enstitüsü, İzmir.

Shearer, D. D., Kohler, F. W., Buchan, K. A., \& McCullough, K. M. (1996). Prompting independent interactions between preschoolers with autism and their nondisabled peers: An analysis of self-monitoring. Early Education and Development, 7, 205-220.

Sofronoff, K., Attwood, T., Hinton, S., \& Levin, I. (2007). A randomized controlled trial of a cognitive behavioural intervention for anger management in children diagnosed with Asperger Syndrome. Journal of Autism and Developmental Disorders, 37, 1203-1214.

Strain, P. S., Kohler, F. W., Storey, K., \& Danko, C. D. (1994). Teaching preschoolers with autism to self-monitor their social interactions: An analysis of results in home and school settings. Journal of Emotional and Behavioral Disorders, 2, ss. 78-88.

Tok, E.S. (2014). Çocukluk çă̆ı anksiyete bozukluklarında Bilişsel Davranışçı Terapi: Korku avcısı programının etkililiği (Yayınlanmamış Doktora Tezi). Ege Üniversitesi, Sosyal Bilimler Enstitüsü, İzmir.

Uçar, T. (2014). Gebelere uygulanan bilişsel davranış̧̧ tekniklere dayalı doğum korkusuyla başetme eğitim programının doğum korkusu ve doğum sürecine etkisi (Yayınlanmamış Doktora Tezi). Cumhuriyet Üniversitesi, Sağlık Bilimleri Enstitüsü, Sivas. 